\title{
Megaproject Performance, Value Creation and Value Distribution: An Organizational Governance Perspective
}

DOI:

10.5465/amd.2020.0029

\section{Document Version}

Accepted author manuscript

Link to publication record in Manchester Research Explorer

\section{Citation for published version (APA):}

Gil, N., \& Fu, Y. (2021). Megaproject Performance, Value Creation and Value Distribution: An Organizational Governance Perspective. Academy of Management Discoveries. https://doi.org/10.5465/amd.2020.0029

\section{Published in:}

Academy of Management Discoveries

\section{Citing this paper}

Please note that where the full-text provided on Manchester Research Explorer is the Author Accepted Manuscript or Proof version this may differ from the final Published version. If citing, it is advised that you check and use the publisher's definitive version.

\section{General rights}

Copyright and moral rights for the publications made accessible in the Research Explorer are retained by the authors and/or other copyright owners and it is a condition of accessing publications that users recognise and abide by the legal requirements associated with these rights.

\section{Takedown policy}

If you believe that this document breaches copyright please refer to the University of Manchester's Takedown Procedures [http://man.ac.uk/04Y6Bo] or contact uml.scholarlycommunications@manchester.ac.uk providing relevant details, so we can investigate your claim.

\section{OPEN ACCESS}




\section{MEGAPROJECT PERFORMANCE, VALUE CREATION AND VALUE DISTRIBUTION: AN ORGANIZATIONAL GOVERNANCE PERSPECTIVE}

\begin{tabular}{|c|c|}
\hline Journal: & Academy of Management Discoveries \\
\hline Manuscript ID & AMD-2020-0029.R2 \\
\hline Manuscript Type: & Revision \\
\hline Keywords: & $\begin{array}{l}\text {....Stakeholders and Shareholders, Organizational Forms }< \\
\text { Organizational \& Management Theory, Value Creation, Capture, and } \\
\text { Appropriation < Strategy Content }\end{array}$ \\
\hline Abstract: & $\begin{array}{l}\text { This study addresses a long-standing debate as to why escalation in } \\
\text { capital costs is so common over the lifecycle of 'megaprojects' - the } \\
\text { project-based, multi-party organizational contexts that are set up to } \\
\text { develop capital-intensive, long-lived infrastructure. We ground our study } \\
\text { on three case studies conducted with theoretical alertness to a range of } \\
\text { factors that need to be considered from an organizational governance } \\
\text { perspective. Our findings trace cost escalation to fundamental changes of } \\
\text { the project governance structure and concomitant renegotiations of the } \\
\text { value to be created and the value distribution. Specifically we link } \\
\text { substantive cost hikes to, first, early negotiations to agree a value } \\
\text { proposition that unifies a core group of autonomous actors under a } \\
\text { shared form of governance. And second, to collective action problems } \\
\text { that arise as key nonmarket stakeholders are brought into a polycentric } \\
\text { governance structure to encourage cooperation in joint local value } \\
\text { creation activities. We also associate cost hikes, although less } \\
\text { substantive, to market transactions with suppliers and to bilateral } \\
\text { agreements with other nonmarket stakeholders that stay excluded from } \\
\text { direct participation in governance-related decisions. We discuss } \\
\text { implications to our theoretical and empirical understanding of } \\
\text { megaproject behavior and performance. }\end{array}$ \\
\hline
\end{tabular}




\title{
MEGAPROJECT PERFORMANCE, VALUE CREATION AND VALUE \\ DISTRIBUTION: AN ORGANIZATIONAL GOVERNANCE PERSPECTIVE
}

\author{
NUNO GIL \\ University of Manchester \\ Alliance Manchester Business School \\ Booth Street West \\ Manchester, M15 6PB \\ United Kingdom \\ Nuno.Gil@manchester.ac.uk \\ YONGCHENG FU \\ Tianjin University \\ College of Management and Economics \\ 92 Weijin Road \\ Tianjin, 300072 \\ China \\ Yongcheng_Fu@126.com
}

\begin{abstract}
Acknowledgements
The authors are grateful to Senior Editor Christopher Tucci for his leadership in curating this paper and the anonymous reviewers for their insightful comments throughout the review process. We also thank the practitioners within the "London megaproject ecosystem" who volunteered time, know-how and shared data. Further, we thank colleagues who inputted into this research project at different stages including Colm Lundrigan, Jeff Pinto, Carliss Baldwin, Rehema Msulwa, Phanish Puranam, Ilze Kivleniece, Giorgio Locatelli, Ashwin Mahalingam and participants in events at the AoM conferences and the International Megaproject Workshop. Finally, we thank the support of our funders: Project Management Institute (Sponsored Research Program), Alliance Manchester Business School (Strategic Research Fund), and National Natural Science Foundation of China (Grants No. 71871154, 72031008).
\end{abstract}




\begin{abstract}
This study addresses a long-standing debate as to why escalation in capital costs is so common over the lifecycle of 'megaprojects' - the project-based, multi-party organizational contexts that are set up to develop capital-intensive, long-lived infrastructure. We ground our study on three case studies conducted with theoretical alertness to a range of factors that need to be considered from an organizational governance perspective. Our findings trace cost escalation to fundamental changes of the project governance structure and concomitant renegotiations of the value to be created and the value distribution. Specifically we link substantive cost hikes to, first, early negotiations to agree a value proposition that unifies a core group of autonomous actors under a shared form of governance. And second, to collective action problems that arise as key nonmarket stakeholders are brought into a polycentric governance structure to encourage cooperation in joint local value creation activities. We also associate cost hikes, although less substantive, to market transactions with suppliers and to bilateral agreements with other nonmarket stakeholders that stay excluded from direct participation in governance-related decisions. We discuss implications to our theoretical and empirical understanding of megaproject behavior and performance.
\end{abstract}

Keywords: organizational governance, value creation, value distribution, project performance, nonmarket stakeholders, infrastructure

'Megaproject' is a term commonly used to label any form of organizing that is set up to develop capital-intensive, long-lived infrastructure that is shareable in use for an appreciable range of demand, for example, transport systems or social assets like Olympic parks. At the heart of management scholarship on megaprojects is a debate on the factors underlying systematic escalation in the capital cost over the project time (Flyvbjerg, Holm, \& Buhl 2002; Gil \& Pinto 2018; Merrow, McDonnell, \& Arguden, 1988; Miller \& Lessard, 2000; Morris \& Hough, 1987; Staw, 1981). This empirical regularity is problematic in that it might lead to an unjustified perception that megaprojects tend to 'fail' (Lundrigan, Gil, \& Puranam 2015). This in turn can 
needlessly put off capital investment in new infrastructure, intermediate goods that are critical to create economic value and social welfare (Frischmann, 2005). ${ }^{1}$

Numerous ideas and hypotheses to explain megaproject (under)performance have been formulated in the last three decades. But extraordinarily, the debate has struggled to move forward (c.f. Denicol, Davies \& Krystallis (2020) for a recent review). Holding back the debate are fundamental differences in the assumptions that are espoused by competing groups of explanations as to the organizational governance of a megaproject (Gil \& Pinto, 2018). Organizational governance relates to the rules and procedures that control resource accumulation, development and allocation; the distribution of the organization's production; and the resolution of disputes (Chandler, 1962; Williamson, 1985). In a megaproject, the organizational governance structure is thus responsible for the decisions that set the project performance targets for scope, cost and end date, as well as that determine the focal organization's ability to stay or not within those targets.

One broad group of explanations for cost escalation implicitly assumes that the organization in charge of mustering the capital and project management - so-called the 'promoter' - has complete authority to make decisions related to the nature of the interactions with nonmarket stakeholders (eg monopolistic users, regulators, interest groups, activists, local communities) and suppliers, as well as to determine the value to be created and how this value is to be distributed. By assuming that the promoter's

\footnotetext{
${ }^{1}$ Before the Covid-19 pandemic, OECD estimated $\$ 70$ trillion was needed in new infrastructure by 2030 to support the world's growth and development. Mirabile, M, Marchal, V, Baron, R. 2016. Technical note on estimates of infrastructure investment needs. Investing in Climate, Investing in Growth, OECD
} 
managers are the ultimate decision-makers on governance matters, scholars have attributed capital cost escalation, at best, to managerial incompetence (Flyvbjerg et al., 2002; Morris, 1994; Morris \&Hough 1987; Staw, 1981; Stinchcombe \& Heimer, 1985) and to changes in the external environment that are beyond the control of the project managers (Love et al. 2018). At worst, capital cost escalation has been attributed to the dishonesty of the promoter's leadership team (Flyvbjerg et al., 2002, Wachs 1989).

Yet, the assumption that managerial authority is the primary mechanism to obtain stakeholders' cooperation has been disputed, and so too the above explanations for cost escalation. Hence another group of studies claims that cost escalation is rooted instead in the fact the promoter shares decision-making authority on governance matters with key nonmarket stakeholders with whom it has high task and/or outcome interdependence (Gil \& Pinto, 2018; Lundrigan et al. 2015; Miller \& Lessard, 2000; Rittel \& Webber, 1973). When decision rights are shared, the promoter is accountable to the stakeholders and its leadership position is only secure if it plays a facilitator role in reaching a collective agreement on a value distribution that all perceive fair. This leads to consensus-oriented talks on scope, putting pressure to relax the cost target.

In this study, we reconcile competing explanations for megaproject performance by mobilizing a novel cognitive lens to make sense of megaproject behavior in the tradition of abductive research (Charles, 1931; Van de Ven, 2007). We draw on recent theoretical advances linking governance adaptation to value creation and value 
capture (Klein et al. 2012, 2019). This work integrates insights from organizational theory (Scott, 1995) with insights from new institutional economics (Libecap, 1989; Ostrom, 1990; Williamson 1993; Dorobantu, Kaul \& Zelner 2017; Odziemkowska \& Dorobantu 2021). In line with the notion an infrastructure is a shared means to many ends (Frischmann, 2012), and inclusive definitions of value (Garcia-Castro \& Aguilera, 2015), we define value as the sum of the economic benefits and social gains to be accrued from a new infrastructure development minus the capital costs to be incurred.

We ground our study on an original dataset that pieces together qualitative and quantitative data on the governance and capital cost performance for three recent megaprojects: the London 2012 Olympic park ('Olympics'); Crossrail, a high-capacity railway linking outer East and West of London; and the Heathrow airport Terminal 2 (T2). We diversified the sample to increase the generalizability of our claims and explore boundary conditions (Siggelkow, 2007). So, we varied the sample by including megaprojects from three economic sectors and by varying the source of finance (public vs. private). We also included megaprojects with movable and immovable end dates.

Our findings uncover a verifiable association between cost hikes and major changes in the megaproject organizational governance. The first governance adaptation relates to the evolution of the promoter's structure early on from a single actor into a temporary alliance by which legally autonomous actors all gain relatively equal say in governance-related decisions and commit to provide mutually supportive 
contributions to joint value creation. As project governance becomes 'shared' (Bridoux \& Stoelhorst, In-press), the alliance members must agree to a value distribution they all find fair, which leads to major increases in scope, and concomitantly, substantive cost hikes.

Second, we trace further substantive cost hikes to a subsequent choice of the promoter to share decision rights on local governance matters with nonmarket stakeholders that control local resources that are essential to value creation. Whilst the promoter still keeps a 'lead role' (Bridoux \& Stoelhorst, in-press) on local governance matters, the promoter commits to collective searches for a fair distribution of the local value to be created. Lead-role governance can be effective to encourage stakeholder cooperation, but can also lead to collective action problems due to a tension between the individual self-interest and collective interest (Hardin, 1968; Olson, 1965; Ostrom, 1990). So, even if the stakeholders agree to cooperate with the promoter, it may nonetheless be advantageous for them to drive a hard bargain to appropriate as much as possible of the value to be created jointly. Then, unless the promoter concedes, an impasse can derail the project; and if the promoter concedes too much, the value captured by the stakeholders can be disproportionate to their contribution. And third, we link less substantive cost hikes to further renegotiations of the value distribution in order to increase the social gains to be accrued, first, from market transactions with the suppliers; and second, from the bilateral, independent agreements with nonmarket stakeholders that were excluded by the promoter from the project governance structure. 
Taken together, our findings trace megaproject cost escalation to governance adaptation and concomitant renegotiations of the value to be created and distributed. Further, they suggest promoters have less ability to forecast reliably the costs of (solving) collective action problems than the costs of trade with nonmarket stakeholders and suppliers. By conducting fieldwork with theoretical alertness to organizational governance, we thus offer a novel perspective on megaproject behavior.

We organize this essay as follows. We first analyze the governance assumptions underlying main research strands in the megaprojects literature. We then explain our methods. After presenting our analysis, we discuss how our findings can be leveraged towards the development of a theory of megaproject organizational boundaries, value creation and value distribution. We conclude by discussing how our work can be a building block towards the development of a grand model of megaproject behavior.

\section{AN ORGANIZATIONAL GOVERNANCE PERSPECTIVE ON MEGAPROJECT PERFORMANCE}

The debate on why cost escalation is endemic to megaprojects has unfolded mainly in the project management (PM) literature, and thus has long been rooted on the project's 'golden triangle', by which performance is evaluated against the initial targets for budget, time and scope. This professional norm is deep-seated albeit a chorus of critiques for emphasizing too much control over flexibility and novelty (Lenfle \& Loch, 2010; Shenhar \& Dvir, 2007). This norm also leaves the promoter facing a conundrum. On the one hand, it puts pressure to commit early on to performance targets and reduce ambiguity in the value proposition. But any target 
overruns then lead to perceptions of underperformance, undermining the promoter's legitimacy to use the resources that it acquired after promising to deliver within target (Denis, Langley, \& Rouleau, 2006).

In light of this conundrum, three research strands stand out in the megaprojects literature from an organizational governance optic. Implicit in a first strand is the idea that the promoter is the ultimate decision-maker on governance matters. In other words, it is assumed that megaproject governance follows a 'hub-and-spoke model' (Bridoux \& Stoelhorst, in-press) with the promoter as the hub and the stakeholders and suppliers at the end of spokes that only relate to the hub through independent, bilateral relations. And so, one story goes, key reasons for cost overruns are the promoter's lack of managerial capabilities (Morris, 1994) and unfettered optimism bias (Flyvbjerg et al., 2002). Organizational psychologists too adopt the same implicit governance assumption. But they link cost hikes to a decision-maker's tendency, in situations where all the options are undesirable, to escalate commitment to failing courses of action and allow sunk costs to dominate decisions (Staw, 1981; Staw \& Ross, 1989). ${ }^{2}$ More controversially, some scholars claim, although evidence is really scant, that cost overruns are rooted in strategic misrepresentation (aka 'lying') because of incentives in the budgeting process and agency problems (Flyvbjerg et al., 2002; Wachs, 1989).

\footnotetext{
2 This claim agrees with the behavioral theses that managers are prone to optimism bias only in situations where "choice is among options that can be considered attractive, although risky", and managers often show an unjustified risk aversion due to reluctance to take responsibility for possible losses (Kahneman \& Lovallo 1993).
} 
The assumption the promoter's managerial authority is the primary mechanism to obtain cooperation from project participants also informs a second research strand that focus, however, on the escalation in project supplier costs (Stinchcombe \& Heimer, 1985; Verweij, van Meerkerk, \& Korthagen, 2015). This research claims supplier cost overruns are due to a promoter's tendency to adopt an arms-length approach by which supplier relations get competitive and managed based on power differences albeit the uncertainty that characterizes the buyer-supplier relations (Gil, 2009; Pitsis, et al. 2003). Yet, a notorious shift in the last decade towards forms of contract that encourage suppliers to cooperate, be flexible and efficient has failed to improve predictability in megaproject supplier costs (Davies et al. 2014). This leaves it unclear if the cost hikes are not instead better explained by supplier opportunism. This is, by the idea that suppliers bid low to win a job with a view to increase profit ex-post contract award by threatening to hold up the work or litigate unless they are compensated for changes to the contract (Winch, 2010).

The assumption that megaproject promoters have complete managerial authority has been challenged, however, by a third research strand. In a seminal study, Miller and Lessard (2000) claim the promoter is to a degree "hostage" to interrelationships and obligations to stakeholders who are not suppliers. This claim resonates with the idea that planning a megaproject is not a "tame" problem which allows for decent forecasting, but rather a "wicked" problem determined by a plurality of objectives held by pluralities of politics (Rittel \& Webber, 1973). In agreement, recent empirical studies trace cost escalation to the diffusion of the authority on governance matters 
(Gil \& Pinto, 2018; Gil \& Tether, 2011). Hence, these studies suggest the promoter is one decision-maker among many and its managers are stewards accountable to stakeholders who control valuable resources such as regulatory consents and property. By assuming that the promoter takes a 'lead-role' (Bridoux \& Stoelhorst, in-press) in the local searches for mutually consensual solutions, this research strand takes a much more benign view of cost overruns. This view concurs with studies in public administration (Moore, 1995; Nutt, 1999) and economic development (Hirschman, 1967), both of which claim that the performance evaluation of complex organizations needs to look both at efficiency and effectiveness as well as to a diagnosis of political expectations in terms of justice and fairness, and to a calculation of what is operationally feasible.

Extraordinarily, three decades of research have achieved no progress in reconciling the above research strands, with some scholars recently choosing instead to trade barbs, demolish each other's research, and engage in ad hominem attacks. ${ }^{3}$ Making it hard to move forward the debate have been obstacles to access research sites to open the megaproject "black box". As such, hypotheses such as optimism bias, deception and incompetence that play to common conceptions remain hard to verify or refute. Further, we still know little about the relative impact on megaproject overall cost performance of (solving) collective action problems vs. hikes in the costs

3 For a nonpartisan report, see Foster, A. 2018. Academics clash on causes of transport cost overruns. Local Transport Today, 27 April. 
of the supplier contracts. And crucially, if we accept claims project promoters often overestimate the benefits (Flyvbjerg et al. 2002), how can we argue megaprojects are not value destroying? We turn now to our methods to explore as to why megaprojects behave the way they do.

\section{RESEARCH METHODS}

Our research design combines multiple case study research with an exploratory panel data analysis. We started the research by conducting three in-depth case studies given the suitability of case research to explore novel ideas by incorporating contextual and temporal dimensions (Eisenhardt \& Graebner, 2007). Through case analysis, we uncovered a systematic association between cost hikes, governance adaptations, and renegotiations of the value distribution. To verify and qualify these associations, we conducted an exploratory panel analysis - a technique that allows regressing a dependent variable whilst controlling for time-invariant heterogeneity (Bartels, 2008).

Our sample includes three megaprojects for which we gained unprecedented access to governance and cost data. We summarize in Table 1 the characteristics of each case, the actors interviewed, and the archival database. In all cases, there was a major renegotiation of the value distribution early on: the Olympics evolved from building an Olympic park into also building wider infrastructure to catalyze urban regeneration (Gil \& Lundrigan, 2012); Crossrail started as an inner London's train but evolved to become a commuters' railway (Gil \& Lundrigan, 2013); and the initial plan for the Heathrow T2 campus revolved just around a single new concourse (Gil \& 
Lundrigan, 2012a). The geographical proximity of the project sites enabled us to conduct all the interviews through a series of trips to London spread between 2011 and 2015. But data collection lasted until the end of 2020 in order to acquire extra data for the panel analysis and to factor in the latest developments of the ongoing Crossrail case.

Insert here <Table 1 Characteristics of the Sample, Interviewees, and Archival Data $>$

Our sample varies three attributes of megaprojects to explore the generalizability of our claims. First, the cases differ by the source of finance. We expected decisions to be politicized in the public projects (Olympics, Crossrail) since the ultimate power to make decisions rested with politicians - voters' agents expected to provide public goods and information about benefits and costs, but also elected leaders incentivized to provide transfers to key constituents and shift costs to others (Johnson \& Libecap, 2001). Yet, we were unclear how much this attribute weighed on governance choices and affected performance, and thus included the T2 case since the Heathrow airport was privately owned. As well as this, collective action theory predicts that cooperation is harder in one-off interactions than in repeated interactions (Ostrom, 1990). Hence, to control for this attribute, the cases differ in terms of potential for prior and future cooperation between the core participants. Specifically, the Olympic park was a one-off venture, whereas the T2 core participants had a long history of cooperation. And Crossrail was a hybrid in that it was the first commuter rail promoted jointly by the UK and London governments, but a second scheme was already being planned. Further, our sample varies in the flexibility allowed in the 
project end dates to control for the effects of this attribute since decisions under collective action are hard to rush (Ostrom 1990).

\section{Data Collection}

We built our dataset by triangulating data obtained through semi-structured interviews, analysis of public and confidential archival documents, and on-site visits. Triangulation is critical in organizational performance studies because the accuracy in people's recollections is vulnerable to revisionism and self-aggrandizement (March \& Sutton, 1997). Further, settings with diffused authority are rich in discrepancies between what people say and factual performance (Denis et al., 2011). To guard against account bias (Eisenhardt, 1989; Miles \& Huberman, 1984), we interviewed top and middle managers working for the promoter, key stakeholders, and major suppliers.

The fieldwork began in 2011 after we gained access to the top managers of the Olympic Delivery Authority (ODA), a public agency set up by the UK government to manage the Olympics project. Armed with the ODA's endorsement and a list of interviewees, we lined up comparable groups of interviewees at Crossrail and T2. All in all, we conducted 88 interviews, one to two-hours long. We also invited eight managers to give public talks, and took verbatim notes of their presentations and lunch chats. We always offered to make the quotes anonymous to avoid potential bias (Podsakoff et al. 2003). The interviews, presentations, and informal chats were complemented by analysis of the archival documents and press articles (Table 1). To help make sense of the data and identify gaps, we wrote a factual account of each 
megaproject lifecycle, which we then shared with key respondents (Gil \& Lundrigan, 2012, 2012a, 2013).

Faced with critical gaps in our dataset, in 2015, we negotiated access to cost data and design change logs for the three cases. ${ }^{4}$ The budget of a megaproject is often made public, but promoters rarely disclose how that budget splits between actual cost forecast (anticipated final cost) and contingency fund. The latter is a form of financial slack that gives the promoter a buffer of utilizable resources in excess of the minimum necessary to produce a specified level of output (Bourgeois, 1981; Cyert \& March, 1963). Budget data reveals little of the inner workings of a megaproject because until slack runs out, the promoter can draw down from the contingency to hide cost hikes whilst claiming the project is 'on budget'. We first gained access to Crossrail cost forecast data after committing not to share any data file. We signed a similar non-disclosure agreement with BAA to access T2 cost data and used a Freedom of Information Request to access Olympics cost data. These datasets enabled us to verify cost and budget data gleaned from public sources and build accurate charts depicting the concomitant evolution of project governance structure, cost forecast and budget. Further, they enabled us to conduct data panel analysis to verify the statistical significance of the associations.

We now turn to present our analysis. We first use the Crossrail case to illustrate our core argument, and then use two vignettes, one on the Olympics case and another

4 A design change log is a document, often in the form of an Excel spreadsheet, that lists the design changes that had a material impact on the cost forecast, the scope of the change, and the reason for it 
on the T2 case to explore boundary conditions. Appendix I shows the panel data analysis.

\begin{abstract}
ANALYSIS
Our analysis across the three cases systematically uncovers a link between cost hikes and four major adaptations of the project governance structure and concomitant renegotiations of the value distribution. In the first adaptation, the promoter's structure evolves from a single organizational actor with complete authority on governance matters into an alliance between legally independent actors under a shared form of governance. In the second, groups of key stakeholders who are not suppliers gain rights to directly participate on governance-related local decisions. In the third, the project governance adapts by adding many independent, bilateral agreements with stakeholders who were excluded from directly influencing project governance matters. And the last adaptation adds a vast supply chain governed by market transactions.
\end{abstract}

The Crossrail case, illustrated in Figure 1, is a good example. The black dashed line in Figure 1a represents the evolution of the cost forecast (anticipated final cost) and the black line the budget (cost forecast plus contingency fund)..$^{5}$ In Figure 1b, we represent the governance adaptations: the blue line shows the evolution of the structure of direct participation on governance matters from a single organizational actor into an alliance before key stakeholder groups join in. The red line shows the

\footnotetext{
5 In the UK context, the contingency fund is defined as the capital that is available to tackle 'unpredictable responses and requirements of stakeholders' (HM Treasury 2020. The Green Book: Central Government Guidance on Appraisal and Evaluation. Open Government License). All cost figures in undiscounted prices were converted into final prices (cash prices) using the rates published by the Green Book and a standard cost profile
} 
growth of the independent, bilateral relationships with other nonmarket stakeholders. And the green line shows the growth of the supplier transactions. Table 2 presents an illustrative summary of the Crossrail qualitative evidence that we gathered from primary material.

Insert <Figs 1a,b: Evolution of the Crossrail Cost, Budget and Governance Structure $>$

Insert <Table 2:Crossrail Governance, Value Creation and Distribution, and Cost Escalation with Illustrative Quotes from Primary Material>

\section{Governance Adaptation 1: Shared Governance Core Formation}

Because megaprojects are large-scale enterprises, a single organizational actor rarely has sufficient resources to pursue the 'grand idea' alone. Thus, that actor seeks to form a temporary alliance for the project duration with other legally independent actors to pool resources in the pursuit of a value distribution that motivates all the parties to volunteer resources to the enterprise. Since an alliance is a voluntary arrangement that involves a shared form of governance by which all its members have relatively equal say (Powell, 2003; Williamson, 1985), its members must negotiate a unifying proposition for joint value creation as well as how this value is to be distributed.

The Crossrail case is telling. Whilst the first concept for a cross London railway emerged in 1974, the UK government alone systematically failed to muster the resources necessary to pursue the idea. The last failed attempt occurred in 1996 when the government shelved a plan to develop a $£ 2.5 \mathrm{bn}$ (1991 prices) $9 \mathrm{~km}$ central London rail, for which it legally safeguarded nonetheless the right to buy the land on the route. 
This plan was only to gain a major boost 5 years later when a temporary alliance was set up with Greater London Authority (GLA), the governance body of London. To manage the project on the alliance's behalf, the UK government (through the Department for Transport, DfT) and GLA (through Transport for London, TfL) set up a public agency in the form of 50-50 joint venture, Cross London Rail Links (CLRL). ${ }^{6}$

\section{Negotiating a unifying value distribution}

The plan to build a central London line was 'high-value for money' from a UK policy perspective since its Benefits-to-Cost Ratio (BCR) was 3.2-3.8. ${ }^{7}$ Still, the two alliance members disagreed on the value to be created jointly - "GLA saw Crossrail as an extension to the underground system. DfT saw it as a major heavy rail system going through London", said one CLRL manager. The disagreement was rooted in different approaches to assess value: the UK government measured benefits in terms of user willingness to pay ("the passengers who will benefit should meet the cost of it", said one Minister ${ }^{8}$ ). But for GLA there were wider economic benefits and social gains that should be factored in, which justified a greater capital investment ("railway schemes have rarely, if ever, paid for themselves in fare revenue", said a CLRL manager ${ }^{9}$.

After three years of talks, the two parties agreed to let Crossrail evolve into a $118 \mathrm{~km}$ commuter's train, which caused a major cost hike, as Figure 1a shows, as well

\footnotetext{
${ }^{6}$ CRCL name later changed to Crossrail Ltd (CRL). For simplicity, we use CLRL throughout the account

${ }^{7}$ Shadow Strategic Rail Authority (SSRA) 2000. London East-West Study

${ }^{8}$ Crossrail Project Funding. Letter to Secretary of State. GLA

${ }^{9}$ Buchanan, P., Arter, K., Buchanan, C. Meeks, R. 2006. Agglomeration Benefits of Crossrail. Association for European Transport
} 
as a BCR drop to $1.99 .{ }^{10}$ Yet, an independent review saw no reasons for alarm in the face of wider economic benefits (eg 7\% productivity increase, agglomeration benefits) and social gains $(110,000$ new jobs $) .{ }^{11}$ In response, the UK government changed the appraisal policy to account for wider economic benefits (but not social gains). This change was enough to lift the BCR to 2.4-2.6, unlocking wide political support for Crossrail - “it's an investment we can't afford not to make", said the Prime Minister. ${ }^{12}$

\section{Governance Adaptation 2: Lead-role Governance Expansion}

Once the promoter members settle on a unifying value distribution, the attention shifts to acquire complementary resources that are essential to value creation. These resources are controlled by groups of key stakeholders such as users, interest groups, and local authorities that are sovereign entities and thus cannot be internalized in the promoter's organizational structure. Yet, to encourage these stakeholders to cooperate and volunteer valuable resources, eg know-how, consents, the promoter can commit to share decision rights over the use of the promoter's own resources. As local groups of decision-making are set up so each group can collectively agree the local value to be created jointly, the promoter loses the last word on how the local conflicts are to be resolved and the governance structure of the project becomes 'polycentric' (Gatignon \& Capron, in-press; Gil \& Baldwin, 2013; Gil \& Pinto, 2018; Ostrom, 1990).

\footnotetext{
${ }^{10}$ Cross London Rail Links Ltd 2003. The Crossrail Business Case - Summary, September, p22

${ }^{11}$ Montagne A 2004. Review of the Crossrail Business Case, Department for Transport, 20 July

12 "Blair upbeat on future of Crossrail project", Financial Times, 26 May 2004
} 
Within each local group of collective action, the promoter keeps a 'lead role' on governance matters (Bridoux \& Stoelhorst, in-press). But the promoter is also one decision-maker among many, and thus is accountable to the local stakeholders that also interact among themselves. If the institutions in the context are robust, it is costly for the promoter to break the word on not to let its own authority dominate local decision-making. Thus, the promoter is under pressure to relax the local cost target to enable a value distribution that all the stakeholders in the group perceive to be fair.

The Crossrail case is telling of this adaptation towards a lead-role, polycentric form of governance. Key stakeholders that gained an equal say on local governance matters included local authorities for the areas of the future stations; Network Rail (NR), a firm that controlled the tracks and stations that Crossrail would use outside central London; and private developers with money to finance a station and/or land on where to build a station. In each local group, the promoter took the lead role in a collective search for a mutually consensual solution. The negotiations were time-consuming since the participants had different distributional preferences and could be tempted to pursue their interests at the expense of maximizing joint value creation; one CLRL manager summarized the process:

You do the design, then the politics, then back to the design...it's all iterative... you come up with an idea, work it up into a piece of paper and then react to the comments you get on that. ... you can't separate the politics from the project at this stage; that's one of the difficulties

\section{Renegotiating local value distributions towards more social gains}

At the heart of the renegotiations of each local value distribution were the social concerns of the local stakeholders. The Crossrail's Farringdon station is a first 
example. Given the lack of public toilets in the area, the local authorities asked for toilets in the new station. But the promoter opposed because underground toilets added extra costs and created difficult issues with security ("they're nothing but a nuisance", said a CLRL manager). Unwilling to accept defeat, a ruckus ensued after a local politician asked for the promoter to reconsider their position because 'at the end of the day', he said in Parliament, 'men piss against everything around here'. ${ }^{13}$ To prevent the conflict from escalating further, the promoter caved in - "power to the people", said a manager.

A second example is the case of the Woolwich station, which the promoter initially excluded from the Crossrail scope because, in the promoter's view, it lacked economic value. Not conformed, a local stakeholder group asked Parliament to arbitrate a dispute. Convinced by the (social) value of the station, which the stakeholders claimed would unlock 11,100 homes and 5,000 jobs in an area of considerable deprivation, Parliament stated the station would provide "exceptional value for money". ${ }^{14}$ After this ruling, a local working group was created. The negotiations were to last several years until a deal was reached by which a developer agreed to pay for two thirds of the new station costs.

Importantly, once a commitment was made to address the stakeholders' concerns, the promoter found it hard to go back on its word to save money. For example, late efforts by the promoter to discard local commitments it had made early on to

\footnotetext{
${ }^{13}$ Daily Hansard- Debate, Commons Debates, House of Commons, 23 June 2011

${ }^{14}$ Crossrail Bill Committee, First Special Report of Session 2005-06, The Crossrail Bill: Woolwich Station, HC597
} 
champion good station designs outside London quickly backfired ("this creates an outer vs. inner London discrimination”, complained a former Minister. ${ }^{15}$ ) Likewise, late attempts to remove $£ 30 \mathrm{~m}$ links between Crossrail and Tube stations, referred by CLRL managers as 'creeping elegance', raised strong opposition. Thus, as Figure1a shows, albeit major cost swings while trying to resolve the collective action problems, a pattern of cost escalation prevailed - "Crossrail is a very difficult beast to tame", said one manager.

\section{Governance Adaptation 3: Hub-and-Spoke Governance Expansion}

When a promoter shares local decision rights, its leadership position becomes only secure as long as the stakeholders perceive there is fairness in the joint value creation activities. Yet, the stakeholders may be tempted to behave uncooperatively and demand concessions that are disproportionate to their own contributions. Aware of this risk, the promoter can instead centralize governance decisions in the hands of the promoter's managers and enter instead into independent, bilateral agreements with the affected stakeholders to gain direct access to their valuable resources. Still our findings show the costs of contracting for stakeholder resources also systematically escalated as a result of the stakeholders' bargaining power and their demands to appropriate more value.

The Crossrail case is a good example. To acquire the land necessary to cross central London, as well as the rights to materially impact over 12,000 nonmarket stakeholders (eg businesses, property owners, residents), the laws in the environment

\footnotetext{
${ }^{15}$ Hurst, W. 2013. Richard Rogers attacks Crossrail station designs., The Guardian, 28 December
} 
asked the promoter to consult extensively. Each affected stakeholder was managed independently and motivated to sell their property. In situations where prices and other market mechanisms were failing to align interests, the promoter threatened to leverage imminent domain laws to force property sales. Still, some stakeholders did not cave in and asked the Parliament to arbitrate the disputes by lodging formal petitions - "people come out of the woodwork with concerns", said a manager. By then making discrete concessions, the promoter settled all but 113 disputes out of 464 petitions lodged by the stakeholders against Crossrail ${ }^{16}$. For example, to gain powers to run Crossrail under the London City airport, the promoter promised to restrict working hours, vehicle movements, and access routes. Further, it committed to shut down construction during the Olympics - "we're trying to build not just a rail but a legacy of goodwill...where people along the alignment feel loved and listened to", said a Crossrail manager.

All the bargaining to formally contract for stakeholder resources put further pressure on the cost forecast. And so, by 2009, the Crossrail budget reached $£ 18 \mathrm{bn}$, bloating by $£ 2$ bn the 2007 budget, which already included a $£ 5$ bn contingency to account for optimism bias (Figure 1a). ${ }^{17}$ As perceptions raised that the project cost was out of control, a manager insisted that they "had tried to be realistic", whilst admitting that "the costings were so approximate they were just not getting close to

\footnotetext{
16 Bennett S 2017. Crossrail project to deliver London's Elizabeth Line: The Parliamentary Bill Process, Proc. Institution of Civil Engineers.

17 The 2007 budget was a P95 figure, so it had been estimated there would be only 5\% chances of being exceeded; National Audit Office 2014. Crossrail. DfT Report by the Comptroller and Auditor General. HC965. 24 Jan
} 
understanding them". Still, under pressure to bring the Crossrail budget down, the promoter identified $£ 3 b n$ of savings by a raft of measures including readjusting construction prices to take advantage of the 2008/09 economic recession, de-risking the project, and delaying the end date. ${ }^{18}$ And so, by late 2010 , and albeit the misgivings of some of the watchdogs, the Crossrail project moved into construction with an announced $£ 15$ bn budget. ${ }^{19}$

\section{Governance Adaptation 4: Supply Chain Expansion}

The formation of a vast, capital-intensive supply chain governed by market transactions marks the last adaptation of the megaproject governance structure. Critically, this change occurs under circumstances that violate the conditions that transaction cost economic (TCE) scholarship posits lead to low (and predictable) transaction costs (Williamson, 1985, 2003). Transaction costs are the costs of bargaining ex-ante of the contract award to devise safeguards against supplier opportunism as well as the costs of ex-post governance to monitor supplier behavior and resolve conflict. ${ }^{20}$ TCE scholars posit that transaction costs reduce for exchanges characterized by low uncertainty and low asset specificity, where asset specificity is a measure of the non-redeployability of the supplier investment in the supplier-buyer relation and can take a variety of forms, eg physical, human, or location (Williamson, 1985, 2003). Specifically, high uncertainty forces the buyer to sign an incomplete contract to be completed through negotiations during the contract period. And so, the

\footnotetext{
${ }^{18}$ National Audit Office (NAO) 2014, Crossrail. Report by the Comptroller and Auditor General. DfT 24 Jan, p22 19 When challenged overtly, Crossrail managers refuted that they had engaged in strategic misrepresentation; one said, "I can't think of a single incident where people deliberately falsified the number and said 'oh, let's just sweep that under the carpet or ignore a cost'; on the contrary, people were usually very conscientious about these things." 20 Supplier opportunism is defined by TCE scholars as 'self-interest with guile' (Williamson, 1985)
} 
supplier may refuse to continue to supply, or to supply at a pre-set level of performance, unless its increased demands are met (Williamson, 2003). Contractual complications can further emerge if asset specificity is high since the buyer's ability to switch suppliers is constrained by the specificity of the investments (Williamson, 2003).

In megaprojects, uncertainty tends to be high in the major buyer-supplier contracts because they tend to be awarded before all the stakeholder disputes on project scope - and thus on the value distribution - have been resolved (Gil, 2009; Pitsis et al. 2003). Further, supplier contracts also often exhibit high asset specificity because they involve location-specific investments, eg in labour and equipment, which can be hard to redeploy or substitute (Winch, 2010). Hence, high uncertainty together with high asset specificity leads to bilateral dependency ex-post contract award, which gives suppliers a monopolistic position and an incentive to behave opportunistically to increase profit.

In agreement with TCE predictions, the Crossrail case reveals major cost hikes with the main supplier contracts. As Figure 1b shows, the supply chain grew rapidly after the promoter gained legal powers to build the railway in 2008 - by late 2011, 97 contracts, all above $£ 50 \mathrm{~m}$, had been awarded..$^{21}$ The specificity and uncertainty of the main contracts were both high. For example, to build the tunnels $40 \mathrm{~m}$ under London, the contractors had to invest in eight tunnel boring machines, each one costing tens of millions of pounds. To motivate the suppliers to cooperate, the forms of contract were

\footnotetext{
${ }^{21}$ Crossrail 2012. Supplementary information for the London Assembly Transport Committee. 29 March.
} 
flexible, if not "too flexible", as one manager said. Specifically, the promoter used, for all major transactions, target-cost contracts with 'pain/gain' share mechanisms to enable the suppliers to share in the benefits of cost savings, whilst bearing some of the cost when overruns occurred. Further, the suppliers were incentivized to flush out any design deficiencies before the target prices were agreed. Notwithstanding this, the suppliers invariably asked for adjustments to the target cost ex-post contract award to compensate for extra work incurred beyond what had been (in their view) contractually agreed. The Crossrail managers suggested suppliers were behaving opportunistically to increase profit ("we're buying in a recession...the old tricks are coming out", said one). But the suppliers - as well as independent reviewers ${ }^{22}-$ claimed the promoter decisions had increased the production costs and thus the compensation was due.

Our analysis cannot untangle if cost escalation in the Crossrail supplier contracts was predominantly caused by extra production work or instead by increases in the transaction costs that were linked to supplier opportunistic demands. But unexpectedly, our findings trace many cost hikes to late renegotiations of the value distribution to further increase the project's social gains. One example was a late commitment to reduce the number of cyclists being overrun by lorries. To this purpose, suppliers were asked to send all drivers to training courses and equip lorries with alarms and sensory devices - "Don't underestimate the amount of demand we're

\footnotetext{
22 KPMG 2019. Independent review of Crossrail - Financial and Commercial. Prepared for TfL and DfT, 23 January; London Assembly (2019) Derailed: Getting Crossrail back on track. Transport Committee. April
} 
going to put in place for goodwill”, a manager said to suppliers. A second example is the procurement of the train fleet. At the time when the Crossrail promoter shorted list the four bidders to manufacture the train cars in 2012, coincidentally, a UK-based train maker (Bombardier) had just lost out a major contract to a German-based manufacturer (Siemens). This led to political fallout, with powerful stakeholders asking about the UK government's support for manufacturing. Despite the extra costs, the promoter pushed back the procurement process to redesign the tender without violating EU procurement rules ("I feel like a man sitting in a cab with three maniacs at the wheel. ..not sure where we'll end up...I just know I'm going to pay the bill at the end", said a manager). When the contract for the train cars was finally awarded to Bombardier in 2014, the promoter could not head off accusations of a political stich-up to protect UK jobs.

Considering that Crossrail moved into construction right after the 2008 financial crisis, it is not surprising the late pressure to increase the social gains from the supplier contracts - "all of a sudden...we started to see that those things were very important... it wasn't a part of the core thinking in 2005 definitely", one manager said. And so, just before construction stopped as a result of Covid-19 to develop new safety protocols, the supplier costs were already 53\% above the 2008 forecast. Still, in the grand scheme of things, the increases in the supplier costs were just a part of the overall cost escalation. 


\section{Expanding Boundary Conditions}

\section{Governance adaptation under well-defined authority: The Olympics case}

The analysis of the Olympics case, illustrated in Figure 2, corroborates the Crossrail account. Still, this case is theoretically significant in that it lets us extend our argument to megaprojects where the promoter's authority is well-defined within a rigid deadline. Like Crossrail, the promoter's structure evolved from a single actor, the British Olympic Association (BOA), who had the idea to bid in 1999, into an alliance between BOA, the UK government, the main capital provider, the Greater London Authority (GLA), the regulator of land use, and the International Olympic Committee (IOC), the brand-owner with rights to set the requirements (Gil \& Lundrigan, 2012). During the talks to agree a shared governance form by which all the four actors gained veto power in the "Olympic board", the top governance body, the value proposition evolved from a $£ 1-£ 2.5$ bn Olympic park towards a regeneration project of East London on the back of the Olympics - "I bid for the Olympics because it's the only way to get the billions of pounds out of the Government to develop... an area neglected for 30 years", acknowledged the London Mayor. ${ }^{23}$ As the four parties agreed to increase the social gains of the Olympics, the cost forecast increased commensurately (Figure 2).

Fig 2 - Olympics: Evolution of Governance Structure, Cost Forecast, and Budget

In 2005, after the UK won the competition, a public agency, the Olympic Delivery Authority (ODA), was set up to manage the project on behalf of the four 
Olympic board members. Unlike the Crossrail case, the UK Parliament rushed to give this agency (through the 2005 Olympics Act) complete decision-making authority to avoid delays if the nonmarket stakeholders were to act uncooperatively ("to get consent to build anything in the UK is such a problem; it's long, convoluted and quite expensive ... the ODA was the exception because it was set up to give itself planning consent", explained an official). The ODA used this authority to force land sales whenever it struggled to align interests ('a very important leverage', one ODA manager put it). But to develop each Olympic venue, given the need to reconcile the heterogeneous interests of local authorities, sport bodies and interest groups (eg architects, disability organizations, environmentalists), the ODA appointed a sponsor to facilitate the search for a mutually consensual solution. As with Crossrail, the collective action problems led to costly renegotiations of the value distributions that increased the value appropriated by stakeholders - "huge spotlight on us in terms of being an exemplar project...the Olympics was going to solve all the world problems," said one manager.

In some cases, norms of cooperation flourished within the local groups. For example, by collectively agreeing to add modular wings to the Aquatics Centre to increase its seating capacity just for the Games, the costs of this venue were contained. ${ }^{24}$ In other cases, collective action problems undermined cooperation. For example, the London bid had pledged to transform the Olympics stadium into an control" (Kelso P. 2008. Olympics 2012 Chiefs willing to spend money like water, say MPs. Guardian, 30 April) 
athletics venue in legacy. But powerful stakeholders demanded to convert it into a football venue, whilst ruling out any financial contribution or a compromise around a multi-use stadium. ${ }^{25}$

Notwithstanding the costs of (resolving) collective action problems, our analysis does not refute the idea that incompetence (or dishonesty) could also be behind cost escalation - "the program management cost forecasts, running at $£ 2 \mathrm{~m} /$ year for 5 years, were utterly unrealistic; no, this is going to run as $10 \%$ of the overall capital cost," said one ODA manager, for example. ${ }^{26}$ Similar to Crossrail, the Olympics project costs continued to rise well after a vast capital-intensive supply chain started to be assembled in 2007, when uncertainty in requirements was still high since it would be two more years before feedback from 2008 Beijing Games would be available. To encourage the suppliers to cooperate, flexible forms of contracts were adopted, but again they did not stop the costs from going up (Figure 2). Still, by drawing on a £2bn contingency built late in 2007, a narrative was sustained until 2012 that the "Olympics was on budget".

\section{Governance Adaptation when most essential resources are 'in': The T2 Case}

In the above accounts, many key stakeholder groups controlled essential resources to value creation, and thus one could argue the governance changes (and

25 After 5 years of inconclusive talks, the idea of a multi-use stadium was agreed collectively. By the time the newly transformed stadium opened in 2014 , the final costs had reached over $£ 700 \mathrm{~m}$ against a $£ 468 \mathrm{~m}$ bid estimate (Stephens M 2017. Moore Stephens Olympic Stadium Review, November. Report made to the Greater London Authority)

26 Indeed, the program management costs were initially estimated so low that they were not even explicitly included in the initial cost forecasts. But by March 2012, they had reached $£ 725$ million (ARUP 2002 London Olympics 2012. Costs and Benefits. Final Report, 21 May; DCMS 2004, London 2012 Candidate File, Department for Culture, Media and Sport, September; Olympic Delivery Authority 2012. Annual report 2011/2012). 
concomitant cost hikes) were rooted in the public nature of the projects. Yet, the privately-financed T2 case shows a similar pattern, illustrated in Figure 3. The idea around T2 dated back to 2002 when BAA, the airport owner, was allowed to build a new terminal (T5) for the One World Alliance (Gil \& Lundrigan, 2012a). ${ }^{27}$ As a regulated monopolist, BAA had an obligation to give a guarantee of parity and treat all the airlines the same, and thus the firm proposed to rebuild the old T2 building for STAR Airlines, a rival alliance that had filed a 'Move under One Roof' request in 2002.

Since BAA had a guaranteed return on capital investment, the company needed consent from the industry regulator. It then took three years of talks for BAA to set up a de facto alliance with the Civil Aviation Authority (CAA) and to agree a value distribution that could unify the two parties. During the talks, the value distribution evolved from a new terminal building into a new airport campus ("in the early days they tended to concentrate on the terminal building, the sexy part, and I kept saying ...you've to look at it as a campus", recalled a STAR director). As a private firm, BAA was under much less pressure to announce cost targets. And thus, only at the end of the talks in 2005, BAA announced plans to build a $£ 1-£ 1.5$ bn T2 campus $^{28}$.

\section{Figure 3 - Heathrow T2: Evolution of the Governance Structure and Cost Forecast}

The $\mathrm{T} 2$ case has theoretical relevance in that since BAA owned the land, the firm controlled most essential resources to value creation. Still, as with the other cases, the

\footnotetext{
${ }^{27}$ In 2012, BAA changed its name to Heathrow Ltd; for simplicity, we keep to the BAA name in our account 28 NCE 2005. "BAA unveiled Terminal 2 plans". November 17, New Civil Engineer
} 
promoter went on to bring key stakeholder groups into the project governance structure - "I worked on Crossrail, and didn't feel that overwhelming involvement by future users as I feel here", said a BAA manager. For example, BAA was only required to consult the STAR airlines ('constructive engagement' in regulatory terms $^{29}$ ). But to encourage cooperation, the airlines were de facto granted decision rights to the extent the construction of $\mathrm{T} 2$ could not start before they signed off the blueprints (Gil \& Lundrigan, 2012a). Consistent with the other cases, collective action problems ensued after the airlines demanded a full-fledged campus, which BAA (and the regulator) claimed was unaffordable unless the airport levies went up, a solution contested by other airlines. Amidst accusations by STAR that BAA and British Airways were "conspiring" to undermine the quality of $\mathrm{T} 2$, mutually consensual solutions emerged after CAA, the airlines and BAA agreed to relax the cost target..$^{30}$

As in the other cases, many key stakeholders such as the local community, activists, and retailers were excluded from the $\mathrm{T} 2$ governance structure. To address their concerns, the promoter too incurred extra capital costs such as by implementing additional measures to mitigate the impact of construction works on the environment or by enhancing the concourse features to meet the needs of retailers. And consistent with the other cases too, uncertainty remained high during the construction process“airlines are so busy trying to survive", said one BAA manager, "that it's impossible

29 The airport regulation stated, "efficient structures for consultation could be expected...It will be for airport operators to decide, through discussions with airlines, the precise nature of the strategic options to be provided" CAA 2005. Airport Regulation. The Process for Constructive Engagement, May, Civil Aviation Authority, pp. $35-6$

30 Johnson, M 2007. Letter from the Star Alliance Project Director to the Civil Aviation Authority, 27 Jan 
for them to think about how they'll operate a building in three years' time". This uncertainty complicated collective action - "I can never get consensus on anything", complained a BAA director. And when less than two years before the planned opening date, a major change in the STAR membership caused the T2 occupancy strategy to fall apart, the promoter invoked its de jure authority to unilaterally impose a late solution and avoid further cost and schedule overruns. To encourage the suppliers to cooperate, flexible forms of contract were also adopted. But as in the other cases, it is unclear if the suppliers then acted opportunistically or not“sometimes we're being accused of being inflexible. I think sometimes BAA is guilty of not listening”, said one supplier.

In sum, our analysis uncovers the pattern of cost escalation-governance adaptation-value redistribution across all cases, widening the boundary conditions of our argument. This pattern is verified by the exploratory panel analysis based on nine major infrastructure components, three from each megaproject, such as sport venues, T2 concourses, and Crossrail stations (Appendix I). Notwithstanding the small sample size, the panel analysis reveals statistically significant correlations between substantive cost hikes with alliance formation (shared governance core) (model 1) and nonmarket stakeholder inclusion (lead-role governance expansion) (models 1 and 2); and between less substantive cost slippages with nonmarket stakeholder exclusion (hub-and-spoke governance expansion) (model 1) and supply chain expansion (model 3). The fact cost escalation was more moderate for T2 suggests that control of more essential resources to value creation leads to less need to adapt governance and 
renegotiate the value distribution. But even in T2, the project managers were accused of misleading the BAA board - "if I had shared how much it was really going to cost with the wrong people...T2 may well have been stopped", said one. This reminds us of the sharp misalignment between the megaproject behavior (as anticipated by the managers) and the environmental and normative expectations which surround these enterprises.

\section{DISCUSSION}

Why is cost escalation so widespread in megaprojects? Is it possible to trace this empirical regularity - at least in part - to governance adaptation? We find it is. Further, we associate cost escalation to a redistribution of the value to be created by the project in order to increase the social gains. As such, performance studies with a narrow focus on economic benefits miss the environmental pressure upon megaprojects to create broad social welfare - "their unspoken responsibility to society", as a respondent put it. We turn now to discuss a model of megaproject governance evolution and how this model can be leveraged into a theory of megaproject organizational boundaries, value creation and value distribution. We conclude by discussing how our work can be seen as a building block towards the development of a grand model of megaproject behavior.

\section{Megaprojects: An Evolving Organizational Governance Structure}

In our definition, a megaproject is a temporary inter-organizational context that is set up to pursue a higher-order goal that revolves around the development of a new capital-intensive, long-lived infrastructure. In Figure 4, we represent in a stylized way 
the evolution of the megaproject organizational governance structure. For the sake of exposition, the four main governance adaptations are represented in a sequential fashion, but they can be expected to overlap to varying degrees in practice.

\section{$<$ Figure 4- The Evolution of the Megaproject Organizational Governance Structure $>$}

\section{Governance adaptation 1: Formation of a shared governance core}

In the first governance adaptation, the megaproject organizational structure changes from a central authority in the hands of a single actor to a shared structure by which governance-related decisions are made by a group of legally autonomous members on a relatively equal basis. The key precursors of an alliance vary from cost minimization to strategic behavior and value maximization drivers (Williamson, 1985). Our findings too reveal variation in the drivers that underlie the formation of the alliances: enhancing a competitive position for acquiring valuable resources was the key driver in the Olympics and Crossrail, whereas cost minimization was central to T2. As the alliance is formed, its members need to agree what value is to be created jointly and the distributive rules by which this value will be divided. Reaching a collective agreement can take years to reconcile conflicting distributional preferences. During the negotiations, the project scope tends to evolve considerably, and concomitantly, the cost forecast tends to escalate. But once reached, a collective agreement tends to lead to a strong commitment to joint value creation activities (Bridoux \& Stoelhorst, in-press). And indeed, across the three cases, no core members defected over the project time. 
As such, the optimism around the very first announcements of performance targets not necessarily is rooted in incompetence or dishonesty. In settings with diffused authority, an organization needs early commitments, especially to numeric targets, to reduce goal ambiguity and gain legitimacy in the eyes of others to acquire more resources (Denis et al., 2011, 2006). Hence, in a megaproject, the actor who has the 'grand idea' is under pressure to set targets early on. But as that actor realizes its dependency on others to create value, a collective agreement needs to be reached on a distribution of the value to be created jointly, which requires openness to increase scope and relax the cost target. Still, since it can be tempting to underestimate targets to make the idea more attractive to others, it cannot be ruled out that optimism bias, either deliberative or as an expression of cognitive bias rooted in judgmental heuristics (Feldman \& March, 1981; Tversky \& Kahneman, 1974), may not weigh on the first announcements.

\section{Governance adaptation 2: Expansion of lead-role governance}

Once a promoter (in a collective form) agrees to joint value creation, it becomes tempting to widen the participation on local governance matters to key stakeholder groups with which there is high task and/or outcome dependence. As these nonmarket stakeholders accept to join local structures of decision-making, not only they are enfranchised and allowed to make claims on the use of the promoter's resources under conditions yet to be specified, but also the stakeholders gain rights to renegotiate the 
value distribution. ${ }^{31}$ This is what the Olympic promoters did with local authorities and sport bodies, or BAA did with the airlines, for example. This adaptation towards a 'polycentric' structure of decision-making responds to basic human cravings for inclusivity and equitability (Fehr \& Gintis, 2007; Ostrom, Walker \& Gardner 1992). Further, by decentralizing governance, the enfranchised stakeholders gain incentives to interact with one another and volunteer resources to local tasks (Gatignon \& Capron, In-press; Klein, Mahoney, McGahan, \& Pitelis, 2019, 2012), which gives legitimacy to the value creation process (Bridoux \& Stoelhorst, in-press). Yet, if the institutions in the context make it costly to shirk the commitment to create value jointly, the promoter's resources become de facto Ostrom (1990)'s common-pool resources in that they conflate high rilvary (or subtractability) with low excludability. In other words, the promoter's capital - as well as the ability to make one-off design choices - both become rivalrous in that their use by one claimant reduces the flow of potential benefits to other claimants; and second, once the promoter agrees to renegotiate the value distribution, it is costly (although not impossible) to renege on this commitment (Gil \& Baldwin, 2013; Gil \& Pinto, 2018). As such, this adaptation of the governance structure leads to collective action problems that can undermine stakeholder cooperation.

Collective action problems in management occur when nonmarket stakeholders find it tempting to pursue their individual interests at the expense of maximizing joint

\footnotetext{
31 An organizational governance adaptation towards lead-role governance is designated by Klein et al. (2019) as an "architectural governance change" in that it combines a renegotiation of the organizational boundaries of the focal organization ('who is in and who is out') with a renegotiation of the distribution of value ('who gets what')
} 
value creation (Bridoux \& Stoelhorst, in-press; Klein et al., 2019). To maximize their share of value, a stakeholder can leverage its bargaining power and strength of property rights. This behavior can yield individual superior outcomes, but if many actors do not cooperate, all are worse off (Hardin 1968; Olson, 1965). In contexts of provision of man-made resources, collective action problems thus lead to "give-some dilemmas" (Barney, 2018; Bridoux \& Stoelhorst 2020; Van Lange et al. 2013). On the one hand, any participant is vulnerable to others pursuing their individual interest by free riding on the participant's effort, a problem of under provision that can make any participant reluctant to cooperate to avoid being exploited. And yet, an individual action that has negative consequences for the self (eg a concession) leads, if performed by enough of the participants involved, to positive consequences for the collective as a whole.

To attenuate give-some dilemmas, our study suggests the megaproject promoter leverages its de jure authority to keep a 'lead role' (Bridoux \& Stoelhorst, in-press) in the negotiations. Further, the promoter restricts the membership of the local groups to keep their size small, which makes it easier to encourage norms of cooperation (mutual trust, reciprocation, compromise) as well as to assure every group member that others are doing that as well (Camerer \& Knez, 1997). Still, even if the stakeholders lack veto power, within each local group, the promoter's managers become 'stewards' (Bridoux \& Stoelhorst, in-press) who are expected to play a facilitator role in reaching a collective agreement on a fair distribution of value. In this role, the promoter often acts cooperatively by relaxing the cost constraint to 
enable consensus. One example is the collective agreement to let the T2 cost slip amidst competing interests between rival airline alliances, both with a relatively equal say in the final decisions. Another example is the collective agreement to scale down the initial vision for the Olympics Aquatics Centre, which required willingness from all the participants to compromise.

Still, when the design of the distributive rules to divide value is not completely centralized in the promoter's managers, a stakeholder can find it tempting to act competitively to capture more value. This can leave the promoter 'hostage' to the stakeholder's interests (Miller \& Lessard, 2000), and relaxing the cost target can then be necessary to avoid an impasse or a defection of a stakeholder that controls essential resources to value creation. This is what happened with the Olympics stadium where the football aficionados free rode on the effort of others by refusing to compromise on a dual-venue solution whilst simultaneously ruling out any contribution to finance their preference for a football stadium in legacy. Although after 5 years of talks the parties agreed to build a multi-use stadium, the unnecessary extra costs to retrofit the stadium incurred by the promoter (had this solution been agreed before building the stadium) led to an outcome poor in legitimacy in the eyes of many (but not all) stakeholders.

\section{Governance adaptation 3: Hub-and-spoke governance expansion}

Given the capital costs of (resolving) collective action problems, our findings suggest that only a subset of the stakeholders are invited to join the megaproject governance structure. To gain direct access to their valuable resources, the promoter 
will instead trade independently with each stakeholder. Whilst these stakeholders exist outside the market and thus are 'nonmarket stakeholders' (Odziemkowska \&Dorobantu 2021, Dorobantu et al. 2017), this governance choice gives the promoter's managers nonetheless latitude to try to align interests by using prices and other market mechanisms, and if need be, regulation. In theoretical terms, this choice reflects a classic cost-benefit calculus: when the transaction costs to acquire a resource are less than the costs of encouraging a voluntary resource contribution, it is more attractive to contract for that resource (Libecap, 1978). This calculus also agrees with the idea that economizing on transaction costs is a key driver for the governance choice by which an organization seeks to acquire resources (Williamson, 1985). This third governance adaptation adds a vast nexus of bilateral contracts with nonmarket stakeholders to the megaproject structure. Within this 'hub-and-spoke' form of governance (Bridoux \& Stoelhorst, In-press), the interaction among the stakeholders is thus not encouraged.

When interactions with stakeholders are primarily bilateral, the conflict resolution mode tends to be different across stakeholders (Mohr \& Spekman, 1994). The forms of conflict resolution vary, ranging from cooperative efforts to overcome disagreements that involve extensive and transparent communication, to power-based conflict resolution modes that involve dominance and confrontation (Agle, \& Wood, 1997; Frooman, 1999; Mitchell, Mohr, Fisher, \& Nevin, 1996). As such, the quality of the bilateral promoter-stakeholder relations varies significantly, and so too the reasons for cost hikes. In some cases, the conflicts are resolved cooperatively. For example, in 
T2, BAA went above and beyond law to align interests with the local communities. But if the stakeholders see no value for them in the project, they lack incentives to cooperate and the interaction can become competitive and managed on a power differential. The use of imminent domain laws by the promoter to force land sales is a case in point. Further, if the stakeholders do not see a legitimate basis for the promoter to claim central authority, and the power differential is in their favor, they can influence managerial behavior. For example, eminent architects used their clout to force the Crossrail promoter to commit to champion good, costly designs for stations outside London. Notwithstanding the extra transaction costs to resolve bilateral stakeholder conflicts, our findings suggest the promoters have greater ability to predict the costs of bilateral trade with stakeholders than the costs of solving collective action problems.

\section{Governance adaptation 4: Supply-chain expansion}

The assembly of a capital-intensive supply chain marks the last major adaptation of the megaproject governance structure. This adaptation adds a series of buyer-supplier contracts to the governance structure. Because the main suppliers tend to be selected before all the stakeholder interactions are resolved, the supplier relations unfold under conditions of high uncertainty. As well this, the relations with suppliers exhibit high specificity since the supplier investments are often location-specific and one-off, and thus can be hard to redeploy to other projects; further it is not easy to substitute a supplier with another one ex-post contract award. These attributes of the transactions with suppliers lead to a bilateral dependency 
ex-post contract award that can encourage the suppliers to exploit uncertainty in order to increase profit (Williamson, 2003). Complicating matters, the one-off supplier exchanges lack the shadow of future or past relationships to foster cooperation, allowing for 'relational forms of contract' (Gibbons \& Henderson 2012), and thus they need to rely instead on contracts enforced by courts.

To motivate suppliers to cooperate under adverse circumstances, our findings suggest the promoters devise contractual safeguards ex-ante. For example, they adopt reimbursable forms of contract, set target costs and pain-gain share mechanisms, commit to use arbitration in case of conflict, and ask suppliers to share actual costs. This agrees with the idea of feasible foresight, which posits that parties to a contract have capacity to look ahead, uncover salient hazards, and devise safeguards to deter ex-post opportunism (Williamson, 1990). Still, our analysis reveals that the costs of the supplier contracts tend to slip. Where our findings are inconclusive is if these cost hikes are rooted in higher transaction costs because the suppliers defect from the spirit of the contract and revert to self-interest bargaining. Or instead, the cost hikes are rooted in bona fide increases in the production costs that derive from the late resolution of stakeholder disputes and unforeseen events. We return to this point in the next section.

\section{Cost Escalation and the Creation of Economic and Social Value}

What is the value that megaprojects create? How is this value distributed? How does it relate to cost escalation? Traditional project appraisal techniques (as used by the UK Treasury Green Book, for example) define value in terms of economic 
benefits minus costs, whilst assuming away any positive externalities because these are hard to observe, verify, and measure. Hence, traditional techniques have an analytical bias towards a narrow range of observable infrastructure uses that is at odds with what is socially optimal (Frischmann, 2012). Still, these techniques are used extensively as a strategy of impersonality to address environmental pressure for accountability and a general distrust of decision-makers (Porter, 1995). In the megaprojects literature too, value is defined in terms of (economic) benefits minus costs (Flyvbjerg et al., 2002), while the stakeholders' social concerns tend to be framed as 'risks' that can lead to cost 'slippages' and 'under' performance (Gil et al., 2015; Miller \& Lessard, 2000).

As such, the choice to decentralize the megaproject governance structure is a way to correct the shortcomings of traditional appraisal techniques. As governance becomes more inclusive by design, the value creation process becomes more democratic, which allows to address uncorrectable market failures and thus create what economists call a 'second-best world' to increase social welfare (Frischmann, 2012). But because the stakeholders' social gains can be difficult to define, count and verify, as beneficiaries, the stakeholders themselves do not want to pay for the costs of their provision. This lack of an immediate interest alignment and inconsistency in payoff structures creates collective action problems. But if we accept that the procedural rationality that guides traditional appraisal techniques distorts by omission, the cost escalation that results from solving collective action problems may have less 
to do with the stakeholders 'free riding' on the promoter's effort and more with agreeing to a fair value distribution..$^{32}$

Still, collective action problems create a risk of stakeholders acting competitively to appropriate more value than the promoter is prepared to accept or can afford. Stakeholders may also try to get away without compromising because they bet the promoter will cave in at the eleventh hour. Further, collective action requires time and (much) discussion to arrive at a decision - as Dietz, Ostrom, \& Stern (2003) say, governing common pool resources is a 'struggle'. Thus, the choice to exclude many stakeholders from direct participation on governance matters aims to avoid excessive conflict in the allocation of the promoter's resources. Our analysis suggests promoters prefer to trade with stakeholders when the exchanges do not involve high degrees of 'reciprocal interdependence' and thus the transaction costs are not anticipated to be prohibitive (Williamson, 1985). In other words, when the stakeholder resources can be decomposable into a contractible transaction that can be defined, counted, and paid for and reciprocal information hiding is high (Baldwin, 2008). For example, in the case of land acquisitions. Yet, pressure from environmental actors to increase the social gains of the exchanges with stakeholders can make the transactions costs hard to forecast too.

32 'Free riding' itself is a rhetorical expression in that one can be deemed a free rider not because the claims are illegitimate but because they are made in a manner that displeases others or exceeds the scope of what the others intended to authorize (Frischmann 2012). 
As the capital-intensive supply chain grows, our findings suggest a renewed environmental pressure to further augment the social value to be created by the megaproject. To this purpose, the promoter and suppliers are bound to engage in a last round of renegotiations of the value distribution. Complicating matters, however, the renegotiations may occur after the award of the supplier contracts, and therefore will interact with the supplier behavior in complex ways given the high specificity of the supplier exchanges. But the cost hikes associated with this last renegotiation of the value distribution are also not as substantive as those from collective action problems.

\section{Megaproject Organizational Boundaries, Value creation and Value Distribution}

Our work uncovers a systematic association between substantive cost hikes and the creation of value jointly with stakeholders such as monopolistic users, regulators, and local authorities, which are outside the project boundaries as traditionally understood. In turn, less substantive cost hikes are associated with bilateral trading with other nonmarket stakeholders excluded from direct participation in governance matters. This raises the question as to the contingencies that specify when each form of governance is more effective to maximize value creation whilst ensuring a fair value distribution.

In collective action situations, property rights are ill-defined because many exchanges take place freely without compensation. Further, collective action is hard to police and individual free-riding behavior cannot be ruled out (Ostrom, 1990). Hence, stakeholder theorists argue voluntary contributions of valuable resources in collective action is almost always conditional on trust and the stakeholders' 
expectations that others will cooperate too (Balliet \& Van Lange, 2013; Bridoux \& Stoelhorst, In-press; Van Lange, et al. 2013). This trust is an outcome of a belief that impersonal structures have been put in place to enable one party to anticipate another party's behavior - what Pennington, Wilcox \& Grover (2003) call "system trust". This contrasts with hub-and-spoke governance where trust tends to be "interpersonal" (Wood \& Gray 1991), and so managers are trusted by stakeholders if they have a legitimate basis for their claim to authority (Odziemkowska \& Dorobantu 2021). Thus, a choice between collective action vs. bilateral trade needs to attend to these mechanisms. This speaks to Ostrom (1990)'s principles of collective action, and the extent the promoter can set in place systems of graduated sanctions and independent monitors, define clear roles and organizational boundaries, and create affordable conflict-resolution structures to reassure stakeholders they will not be the dupe of others if they dispose to cooperate. In other words, if the promoter chooses to make governance more inclusive, it needs to be perceived as a neutral party despite its stake in the outcomes and the heterogeneity in the subgoals and values espoused by the enfranchised stakeholders who were granted decision rights. Further, this governance choice speaks to the promoter's capability to contract beyond the market to access valuable resources, mitigate negative externalities generated by the use of the stakeholder resources, and the capacity of the stakeholders themselves for collective mobilization (Odziemkowska \& Dorobantu 2021).

Another contingent variable that affects the effectiveness of one governance form over the other, and thus affects organizational boundaries, is the level of complexity 
of the joint value creation activities (Bridoux \& Stoelhorst, in-press). In a megaproject, as with any organizational context formed to create 'man-made artifacts' (Baldwin \& Clark 2000; Simon 1962), complexity can be understood in terms of the ability to decouple the design and production tasks for the different functional components (Gil \& Tether 2011; Gil \& Pinto 2018; Tee, Davies, \& Whyte 2021). So, the more modular is the artifact's architecture in that there is one-to-one mapping between functions and components, the less time it takes to understand and resolve local problems. For example, an Olympic park can be decomposed into a set of loosely coupled local systems, whereas a railway is an integral asset where any local solution can affect system performance as a whole (Gil \& Pinto, 2018; Davies \& Mackenzie 2014).

In the Crossrail case, technological complexity did not put off managers from resorting to collective action to encourage stakeholder cooperation. But we need more research on the extent collective action leads to a fair distribution of the value created jointly when the local problems are intertwined. As well as this, will the choice to set up collective action groups be affected by the level of dynamism in the stakeholder interactions? The T2 case shows that volatility in requirements makes it hard to agree to a fair distribution of value. In the face of change, a central authority can be more effective to speed up decisions to adapt the distributive rules and encourage stakeholder cooperation (Bridoux \& Stoelhorst, in-press). In contrast, commons organizations can be slow to adapt to rapid exogenous change, including technology change (Ostrom, 2005: 272). But a lack of interaction among stakeholders in a 
dynamic environment may affect the quality and legitimacy of the decisions, so promoters face a trade-off.

Relatedly, the availability of slack resources, eg contingency funds, is another contingency that may affect the effectiveness of one governance form over the other. In the Olympics and Crossrail cases, high levels of slack worked as a buffer of utilizable resources that enabled to limit the (political) costs of relaxing the cost constraint. Still, slack did not stop cost escalation. In contrast, slack was less substantive in T2 and so were the cost hikes. This leaves it unclear if high levels of slack do not undermine the promoter's bargaining power both in collective action and in bilateral trading with the stakeholders. Hypothetically, high levels of slack may amplify the risk of exploitation of the "larger by the smaller" (Olson, 1965) by transforming the promoter's resources into a more manageable "partially (non) rival good" (Frischmann, 2012). ${ }^{33}$

Also meriting further research are the antecedents of governance choice and the interplay between different project governance forms. Our stylized model depicts a step-by-step governance evolution, but the analysis reveals a more nuanced picture: first, the different governance forms all overlap to varying degrees, creating complex interdependences and feedback loops; and second, the evidence shows megaproject organizational boundaries are not well-defined, but rather fluid and permeable. For example, the Crossrail promoter only created the Woolwich working group after

\footnotetext{
${ }^{33}$ Partially (non) rival resources are also called "impure" public goods to emphasize that the degree of (non) rivalry of consumption varies over time, with the number of users, and is often manageable (Frischmann, 2012: 12)
} 
losing a power battle. And BAA centralized governance after failing to get a consensus with STAR airlines. So, if acquiring nonmarket stakeholder resources is a bottleneck to value creation, what are the antecedents of the governance form to tackle this bottleneck? The attributes of the resource complementarities? A calculus that collective action will not lead to impasse or prohibitive concessions? As well as this, when the promoter brings essential resources 'in' through internalization and voluntary contributions, it is creating a 'transaction-free zone' (Baldwin, 2019) within the project task network wherein the transfers of information, capital, and other resources are dense and complex. This transaction free zone is encapsulated by supplier contracts and bilateral stakeholder agreements. All this suggests many permutations of governance adaptation sequences are possible, and more research is needed on how each one affects the value to be created, the fairness in the value distribution, and the project behavior.

Of course, since megaprojects rarely unfold in conditions of harsh competition, governance choice is unlikely to be a strict function of the one that is more efficient in creating economic value. Rather, it is more likely to be a combination of the managers' appetite for more or less latitude on governance-related matters, social norms in the context, the external institutional environment, and the power differential with key stakeholders. Illuminating how key contingencies affect the effectiveness of alternative forms of organizational governance and the governance adaptation sequences - as well as the promoter's own ability to make a choice - points to a 
direction towards a theory of megaproject organizational boundaries, value creation and value distribution.

\section{CONCLUSION: TOWARDS A GRAND MODEL OF MEGAPROJECT BEHAVIOR}

The debate on megaproject performance has long revolved around cost escalation, almost obsessively, reflecting the classic centrality of budget setting to accountability and control within an organization's management process (Pfeffer \& Salancik, 1978; Thompson \& Jones, 1986). Yet, our model of megaproject governance reveals that managers compensate for this procedural bias by adapting governance and relaxing the project performance targets. This enables a social surplus (the amount by which social value exceeds private value) to be realized at the expenses of economic value creation.

In offering this insight, our work contributes to reconcile competing explanations for megaproject cost escalation by shedding light on how those explanations relate to different elements of governance that co-exist. For example, the ideas of optimism bias and deception remain relevant for bilateral interactions with nonmarket stakeholders in that it is up to the promoter alone to set the targets for those relations. Yet, we also link more substantive cost hikes to decentralized governance, corroborating claims that link costs hikes to collective action (Gil \& Pinto, 2018). Hence, if we accept optimism is needed in collective action to ward off paralysis and that forecasts free of optimism can be self-defeating, destructive and 
demoralizing (Kahneman \& Lovallo, 1993), then realism can potentially do more harm than good in inclusive forms of governance.

Relatedly, our model of governance evolution concurs with claims that trace cost escalation to slippages in supplier costs. What our study shows, however, is that in the grand scheme of things, the hikes in supplier costs are moderate relative to the cost escalation associated with the stakeholder interactions. As well as this, the escalation in supplier costs is intertwined with the interactions with nonmarket stakeholders that remain unresolved ex post contract award to the suppliers. This suggests that, at least, part of the supplier cost hikes may reflect more a late redistribution of the value to be created towards an increase in the social gains, and less suppliers' opportunism.

In sum, a governance perspective paves the way for developing a grand model of megaproject behavior that factors in an array of competing explanations for cost escalation. The relevance of each explanation is a function of a choice between creating value jointly to encourage voluntary resource contributions vs. keeping authority centralized to trade for stakeholder resources. The more governance is made polycentric to include key nonmarket stakeholders, the more megaproject behavior is affected by collective action problems and the promoter's competence to build system trust and lead activities to create value jointly towards a division of value that is perceived to be fair. The more governance revolves around independent, bilateral exchanges with nonmarket stakeholders, the more megaproject behavior - and the extent to which the distribution of the value to be created is fair - becomes a function of the promoter's capabilities to exercise authority and contract in a situation of high 
dependence of tasks and/or outcomes with stakeholders. Incorporating features of centralized and decentralized governance is thus a promising direction to better explain and predict the gap between intentions and outcomes in regards to megaproject behavior, as well as how megaprojects create value and how value is distributed.

Table 1 Summary of Characteristics of the Sample, Interviewees, and Archival Data

\begin{tabular}{|c|c|c|c|}
\hline Cases & London 2012 & Crossrail & Heathrow T2 \\
\hline $\begin{array}{l}\text { Value creation } \\
\text { proposition }\end{array}$ & $\begin{array}{l}\text { Evolved } \\
\text { From Olympic park to urban } \\
\text { regeneration scheme }\end{array}$ & $\begin{array}{l}\text { Evolved } \\
\text { From an inner city London } \\
\text { train to commuters' train }\end{array}$ & $\begin{array}{l}\text { Evolved } \\
\text { From a new airport terminal } \\
\text { building to an airport campus }\end{array}$ \\
\hline $\begin{array}{l}\text { Membership of } \\
\text { the core alliance }\end{array}$ & $\begin{array}{l}\text { \#4 organizational actors } \\
\text { UK and London Govt's; } \\
B O A(\S) ; I O C / L O C O G(\S)\end{array}$ & $\begin{array}{l}\text { \#2 organizational actors } \\
\text { UK government, London } \\
\text { government }\end{array}$ & $\begin{array}{l}\text { \#2 organizational actors } \\
B A A \text { (airport owner), CAA }\left(^{\star}\right) \\
\text { (regulator) }\end{array}$ \\
\hline Key stakeholders & $\begin{array}{l}\text { > } 500 \text { including: } \\
368 \text { property owners; } 35 \text { sport } \\
\text { bodies; } 16 \text { funders; } 15 \text { venue } \\
\text { owners; } 9 \text { transport bodies; } 8 \\
\text { interest groups; } 5 \text { local } \\
\text { governments; } 6 \text { utility } \\
\text { companies; Parliament }\end{array}$ & $\begin{array}{l}\text { > } 600 \text { including: } \\
452 \text { property owners; } 37 \text { local } \\
\text { governments; } 25 \text { community } \\
\text { groups; } 7 \text { utility companies; } 4 \\
\text { transport agencies; } \\
\text { Parliament }\end{array}$ & $\begin{array}{l}\text { } 300 \text { including } \\
120 \text { local residents; } 39 \text { retailers; } \\
21 \text { STAR airlines; } 68 \text { airlines } \\
\text { outside STAR; } 25 \text { public } \\
\text { agencies; } 4 \text { utility companies; } 4 \\
\text { local governments }\end{array}$ \\
\hline $\begin{array}{l}\text { No. suppliers at } \\
\text { peak }\left(1^{\text {st }} / 2^{\text {nd }} \text { tier }\right)\end{array}$ & $\sim 1,700$ & $\sim 2,700$ & $\sim 650$ \\
\hline $\begin{array}{l}\text { Timescale of key } \\
\text { stakeholder } \\
\text { interactions and } \\
\text { outcomes }\end{array}$ & $\begin{array}{l}\text { } 10 \text { years (1999-2008/09) } \\
\text { Outcome: documents setting } \\
\text { performance targets } \\
2005 \text { Bid book; } 2007 \text { Yellow } \\
\text { book; } 2009 \text { Blue book }\end{array}$ & $\begin{array}{l}\text { 12 years (1998-2009) } \\
\text { Outcome: laws safeguarding } \\
\text { land and stakeholder formal } \\
\text { agreements } \\
\text { Safeguarding directions } \\
\text { (2004);2008 Crossrail Act }\end{array}$ & $\begin{array}{l}\sim 7 \text { years (2002-2008/9) } \\
\text { Outcome: Agreement setting the } \\
\text { project scope, cost, and schedule } \\
\text { BAA 5-year Capital Investment } \\
\text { Plan (2008) }\end{array}$ \\
\hline $\begin{array}{l}\text { Timescale of } \\
\text { construction }\end{array}$ & $\begin{array}{l}\sim 7 \text { years }(2006 / 7-2014) \\
\text { including conversion of } \\
\text { Olympic park in public park }\end{array}$ & $\begin{array}{l}\sim 13 / 14 \text { years }(2008 / \\
09-2021 / 22) \text { (forecast as of } \\
\text { Sept } 2020)\end{array}$ & $\sim 5$ years $(2009-2014)$ \\
\hline $\begin{array}{l}\text { Cost forecast } \\
\text { escalation }\end{array}$ & $\begin{array}{l}597 \% \text {, relative to the very first } \\
\text { announcement } \\
64 \% \text {, relative to the arrival of } \\
\text { vast supply chain }\end{array}$ & $\begin{array}{l}513 \% \text {, relative to the very first } \\
\text { announcement } \\
94 \% \text {, relative to the arrival of } \\
\text { vast supply chain }\end{array}$ & $\begin{array}{l}80 \% \text {, relative to the very first } \\
\text { announcement } \\
25 \% \text {, relative to the arrival of vast } \\
\text { supply chain }\end{array}$ \\
\hline No interviews & $\# 36$ & $\# 33$ & $\# 19$ \\
\hline $\begin{array}{l}\text { No. and } \\
\text { description of } \\
\text { organizational } \\
\text { actors interviewed }\end{array}$ & $\begin{array}{l}\text { \#8: } \\
\text { London2012 (bid company) } \\
\text { ODA (promoters' agent); } \\
\text { LOCOG (IOC watchdog); } \\
\text { OPLC (Olympic park } \\
\text { operator); Transport for } \\
\text { London; CLM (program } \\
\text { manager); Land Lease } \\
\text { (private developer); NR }\end{array}$ & $\begin{array}{l}\text { \#8 } \\
\text { CLRL (promoters' agent); } \\
\text { Network Rail; UK Treasury; } \\
\text { Transport for London (TfL); } \\
\text { Canary Wharf (landowner); } \\
\text { Bechtel (program manager) } \\
\text { Transcend (supplier) }\end{array}$ & $\begin{array}{l}\text { \#5: } \\
\text { STAR Alliance, Air Canada, BAA, } \\
\text { HETCo and Balfour Beatty (two } \\
\text { main suppliers) }\end{array}$ \\
\hline
\end{tabular}


No. Documents: \#114

Strategy \& planning: \#74

Strategy \& planning: \#80

Financial reports: \#2

Financial reports: \#6

Formal communication: \#6

Formal communication: \#19

Newsletters \& PR docs: \#23 Newsletters \& PR docs: \#8

Design documents: \#9 Design documents: \#4 Meeting minutes: \#8 Meeting minutes: \#3

logs) Meeting minutes: \#15 Meeting minutes: \#8 Meeting minutes: \#3

(§)BOA - British Olympic Association; LOCOG, London Organizing Committee of the Olympic and Paralympic Games and International Olympic Committee; $\left({ }^{*}\right)$ CAA - Civil Aviation Authority

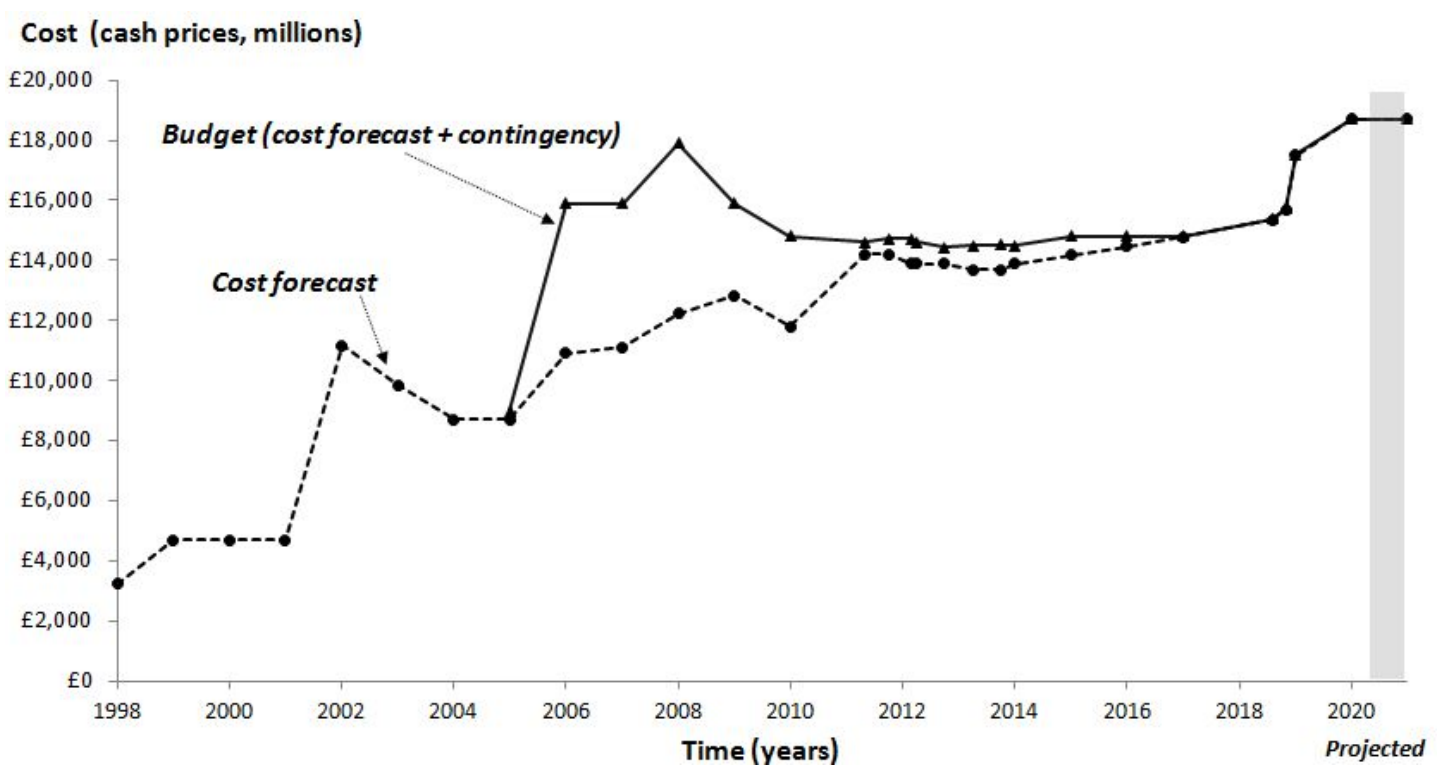

Figure 1 a: Evolution of the Crossrail Cost Forecast and Budget

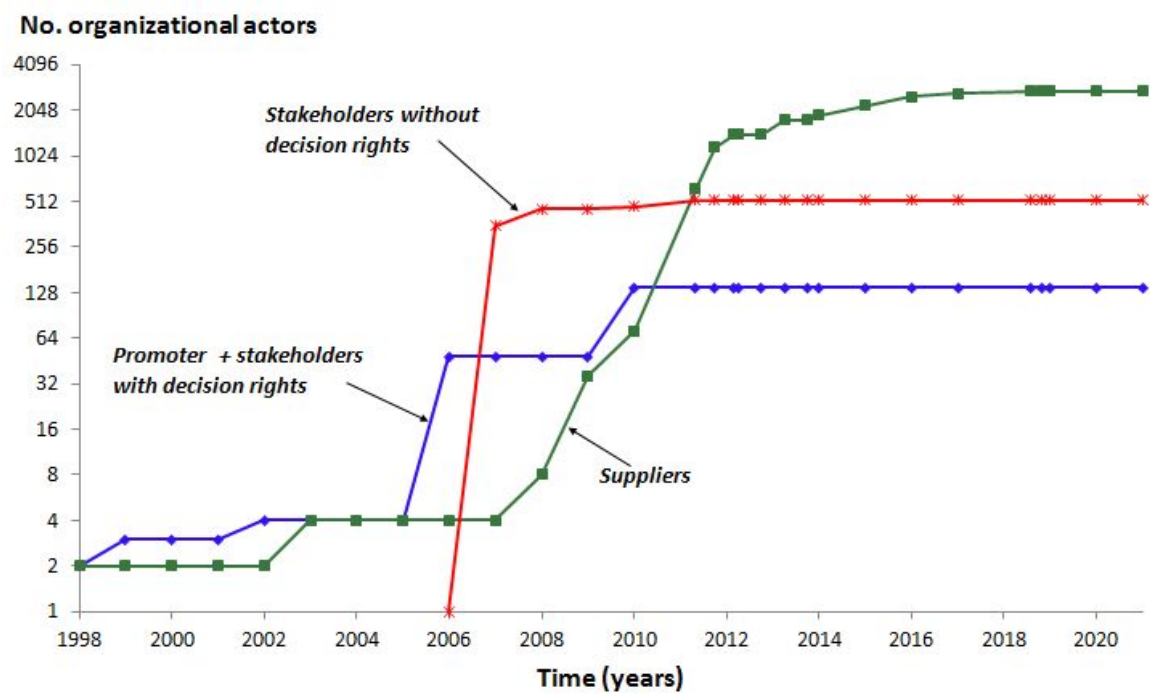

Figure $1 \mathrm{~b}$ : Evolution of the Crossrail Governance Structure 


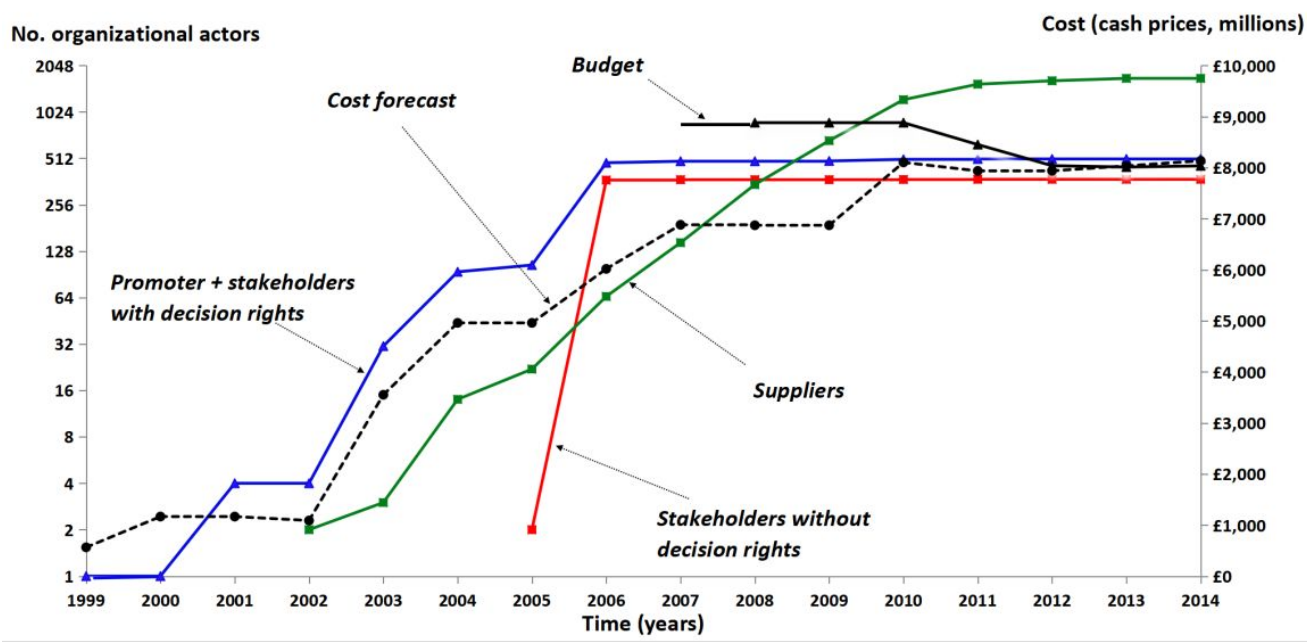

Fig 2 - Olympics: Evolution of the Cost Forecast, Budget and Governance Structure

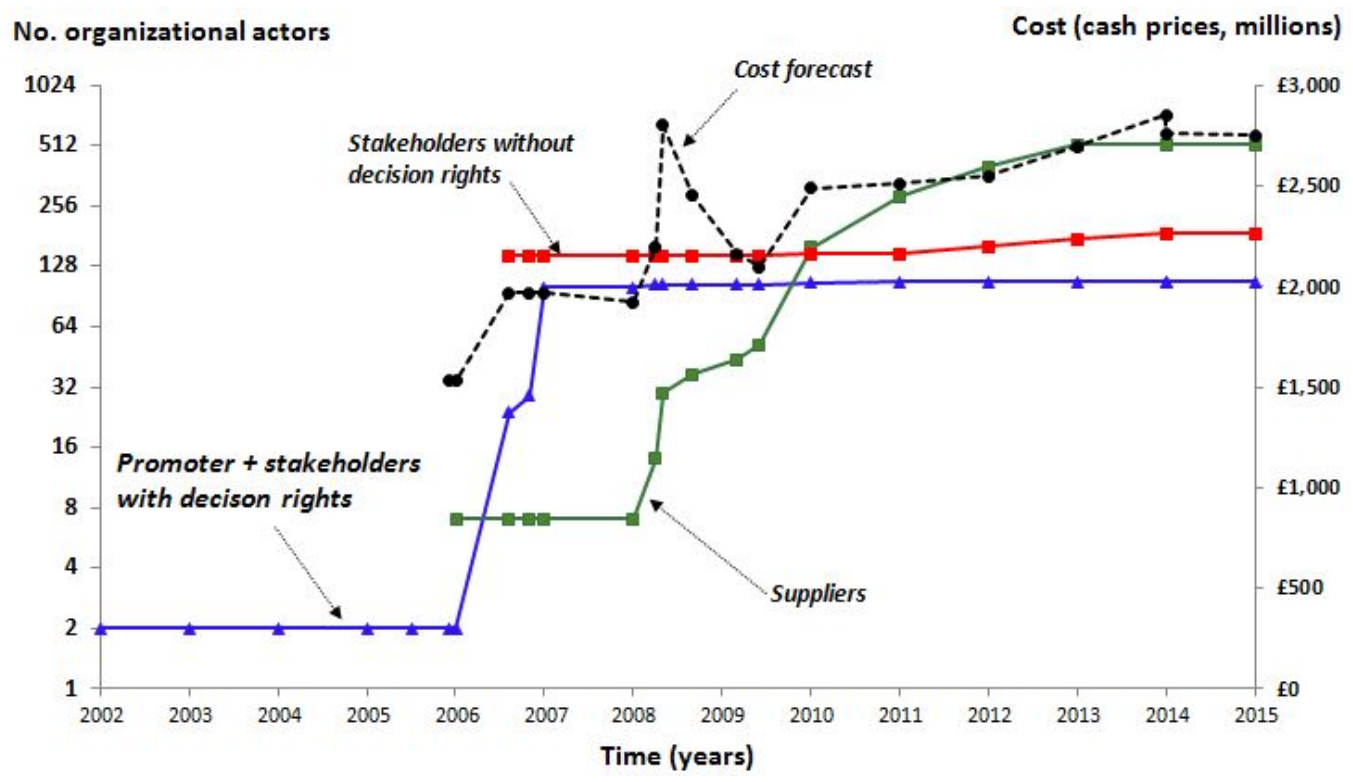

Fig 3 -T2: Evolution of the Cost Forecast, Budget and Governance Structure

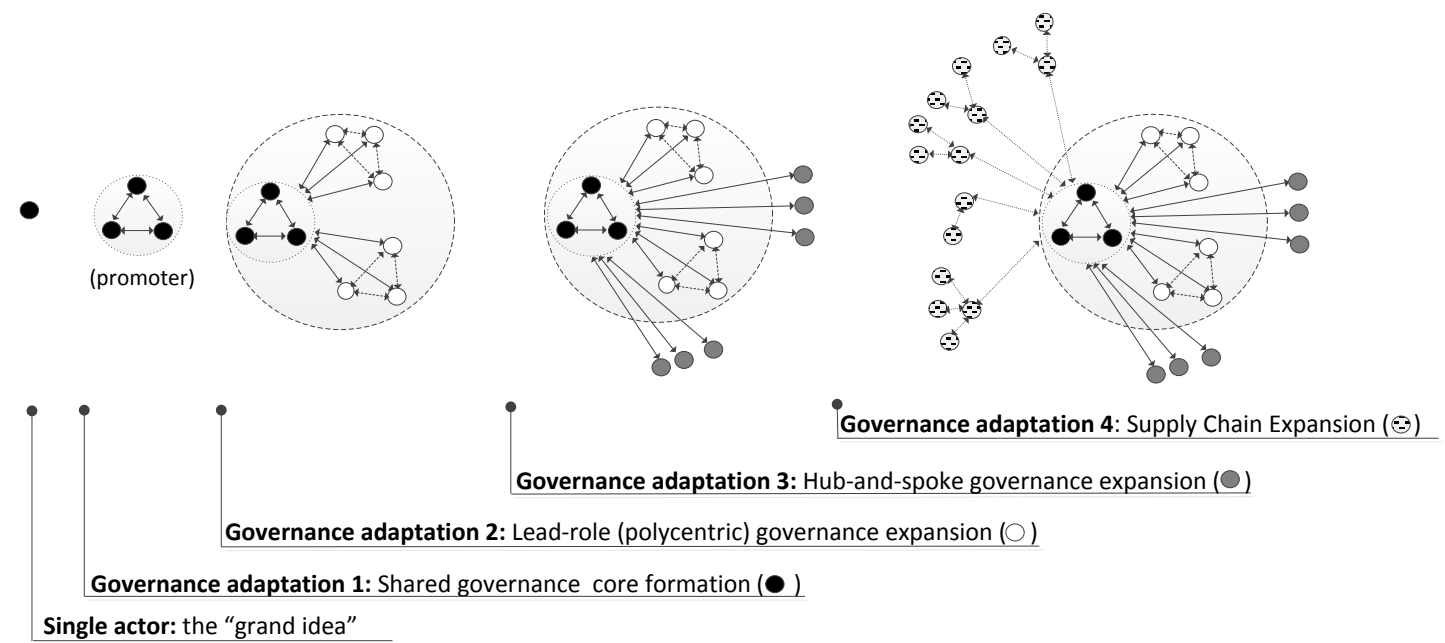

Figure 4- The Evolution of the Megaproject Organizational Governance Structure 


\section{Appendix I - Exploratory Panel Data Analysis}

Our multiple-case analysis reveals a strong association of megaproject cost escalation with governance adaptations. To verify and qualify these findings we used panel data analysis. Specifically, we built a time-series dataset to regress cost escalation, the dependent variable, on measures of governance change. To increase the generalizability of the findings, we formed a sample of nine major infrastructure components, three from each case. Further, we varied the interdependence between components to control for task complexity. Hence, our sample includes modular components such as sport venues and the T2 car park and integral components such as the Crossrail stations and tunnels. Still, the panel data analysis is exploratory given the difficulties to assemble a larger dataset.

To assemble the cost-governance time-series, we combed various data sources. For the early negotiations, we examined feasibility studies and parliamentary reports for the public projects as well as the T2 capital investment plans and investor reports. We also looked at minutes of board meetings, financial memorandums, and public presentations. To identify which stakeholders participated directly in governance-related decisions, we studied governance maps, formal communications, and minutes of board meetings. In addition, for Crossrail, we looked at the petitions lodged by stakeholders in Parliament and promoter responses; for T2, we checked the public consultation records; and for the Olympic park, we checked the compulsory purchase orders. We supplemented this information with data from change order logs, risk registers, and monthly subproject status reports. A typical report includes information on the cost forecast, contingency fund, as well as on supplier selection.

Dependent variables We used cost forecast to measure performance because it reflects the capital committed to foreseeable needs plus an allowance for known risks, and so predicts final cost at any point in time. So, our performance variable compares the cost forecast at period $\mathrm{t}$ (Cost forecast ${ }_{t}$ ) with the cost forecast at a reference point (Cost forecast $r$ ):

$$
\text { Cost escalation }_{t}=\frac{\text { Cost forecast }_{t}-\text { Cost forecast }_{r}}{\text { Cost forecast }_{r}} * 100 \%
$$

We qualified the performance-governance adaptation relationship against three reference points: the very first cost forecast (Cost_E1); the cost forecast before the promoter started to negotiate with stakeholders (whether they were or not part of governance) (Cost_E2); and the cost forecast before the arrival of the capital-intensive suppliers (Cost_E3).

Independent variables We measure governance changes by using four indicators at each time period: number of alliance members; numbers of stakeholders directly participating in or excluded from governance-related decisions; and number of first and second tier suppliers. To control for the risk of correlation between independent variables, we checked tolerance statics to determine if the results might be influenced by multicollinearity. We report the highest and mean variance inflation factor (VIF) in the Tables AI.1 and AI.2. We found no single independent variable with a VIF greater than 10, an accepted threshold indicator of multicollinearity (Gujarati \& Porter, 2009).

Control variables. Our qualitative analysis revealed differing project characteristics could impact cost performance. First, only the Olympics promoter had full de jure authority on governance-matters within a rigid deadline. Second, more control over essential resources affected performance in that the T2 cost slippages were more moderate. And third, the integral architecture of Crossrail made the project less decomposable than the other two. These characteristics are time-invariant, and thus could be quantified by dummy variables. To decide if we needed to include time-invariant variables as explanatory variables, we conducted a Hausman test to compare two models (Greene, 2000; Hausman, 1978). A fixed-effects (FE) model assumes a correlation between time-invariant control variables and independent variables. Hence, in a FE model, time-invariant variables can be omitted because whatever effects these variables have on the dependent variable at one time, they will also have the same effects on a later time. This is, the effects are 'fixed'. And so, any changes in the dependent variable must be due to influences other than the omitted time-invariant variables and the FE estimated coefficients cannot be biased (Allison, 2009; Bartels, 2008; Stock \& Watson, 2007). Alternatively, we could include the control variables as explanatory variables by using a random-effects (RE) model, which assumes the omitted variables are uncorrelated with the independent variables. In the Hausman test, the null hypothesis posits that omitted variables are uncorrelated with other explanatory variables, which implies the 
preferred model is the RE model. After running the test, we found that significant levels in all our models are less than $0.05,{ }^{34}$ rejecting the null hypothesis. So the FE model was preferred, capturing heterogeneities through a constant.

Statistical method We expressed the relationship between megaproject performance and governance using the following generalized equation:

$$
\text { Cost escalation }_{i t}=\alpha_{i}+\beta^{\prime} x_{i t}+u_{i t}
$$

in which Cost escalation ${ }_{i t}$ is the magnitude of the cost escalation for entity $i$ at time $t ; \propto_{i} \mathrm{~s}$ is the unknown intercept for each entity that captures time-invariant individual heterogeneity; $\beta$ is a vector of parameters estimates; $x_{i t}$ is a vector of independent variables for entity $i$ at time $t$; and $u_{i t}$ is an error term. Further, as the independent variable varies by one unit, the cost escalation increases or decreases by $\beta$ units. We have also run regression diagnostics by conducting unit roots and heteroscedasticity tests, all suggesting an appropriate use of the regression model.

Panel data analysis results Table AI.1 summarizes the descriptive statistics and correlations for the variables of interest. In agreement with the qualitative analysis, setting up an alliance is positively correlated with cost hikes $(0.34, p<0.001)$. Further, the cost hikes are positively correlated $(0.45, p<0.001)$ with stakeholder inclusion but negatively correlated $(-0.29, p<0.01)$ with their exclusion, and have no significant correlation with supply chain growth $(0.12, p>0.05)$. To control for impacts of individual heterogeneity and data dynamics we ran a panel analysis.

Table AI.1 Descriptive Statics and Correlations

\begin{tabular}{|c|c|c|c|c|c|c|c|c|c|}
\hline & & Mean & & 1 & 2 & 3 & 4 & 5 & 6 \\
\hline $1-$ Cost_E1 & 1.04 & 1.20 & 1.00 & & & & & & \\
\hline $2-$ Cost_E2 & 0.56 & 0.65 & $0.21 *$ & 1.00 & & & & & \\
\hline 3-Cost_E3 & 0.28 & 0.36 & 0.19 & $0.79 * * *$ & 1.00 & & & & \\
\hline 4 - Core alliance & 3.26 & 0.98 & $0.34 * * *$ & $-0.24 *$ & -0.12 & 1.00 & & & \\
\hline $\begin{array}{l}5-\text { Included } \\
\text { stakeholders }\end{array}$ & 26.9 & 35.93 & -0.01 & $0.45 * * *$ & 0.20 & $-0.34 * * *$ & 1.00 & & \\
\hline $\begin{array}{l}6-\text { Excluded } \\
\text { stakeholders }\end{array}$ & 43.03 & 58.82 & $0.65 * * *$ & $-0.29 * *$ & $-0.37 * * *$ & $0.22 * *$ & $0.9^{*}$ & 1.0 & \\
\hline 7 - Suppliers & 62.16 & 82.99 & $0.32 * * *$ & 0.05 & 0.12 & $0.31 * * *$ & $0.2 * *$ & $0.48 * * *$ & .00 \\
\hline
\end{tabular}

Note: $\mathrm{n}=9$ components and 160 component-year observations

$* \mathrm{p}<0.05, * * \mathrm{p}<0.01, * * * \mathrm{p}<0.001$

Table AI.2 presents the regression outcomes. We recall in Model 1, the final cost is compared to the first cost forecast; in Model 2, it is compared against the cost announced before the start of the stakeholder interactions; and in Model 3, against the cost forecasted just before assembling a capital-intensive supply chain. The $F$ test value is significant in all models, which suggests a good fit with the data. ${ }^{35}$

Table AI.2 - Regression Results for Cost Forecast Escalation

\begin{tabular}{llll}
\hline & $\begin{array}{l}\text { Model 1 } \\
(\text { Cost_E1 })\end{array}$ & $\begin{array}{l}\text { Model 2 } \\
\text { (Cost_E2) }\end{array}$ & $\begin{array}{l}\text { Model 3 } \\
\text { (Cost_E3) }\end{array}$ \\
\hline Core alliance & $0.3233^{* * *}$ & -0.1359 & -0.1590 \\
Included stakeholders & $0.0073^{*}$ & $0.0116^{* * *}$ & 0.0171 \\
Excluded stakeholders & $0.0039^{*}$ & -0.0018 & -0.0046
\end{tabular}

\footnotetext{
${ }^{34}$ When Cost_E1 is the dependent variable, $\chi^{2}(4)=16.15, p=0.0028$; when Cost_E2 is the dependent variable, $\chi^{2}(4)=12.41, p=0.0295$; when Cost $E 3$ is the dependent variable, $\chi^{2}(4)=29.2, p=0.0000$.

${ }^{35} \mathrm{We}$ do not include time-fixed effects because the null hypothesis that the coefficients for all periods are jointly equal to zero was not rejected (Prob $>F$ is $>0.05$ ).
} 
Suppliers

No. of observations

No. of entities

VIF: Highest (Mean)

$F$ test

$\mathrm{R}$ squared

Note: $* p<0.05, * * p<0.01, * * * p<0.001$

Model 1 shows the negotiations between alliance members cause the largest proportion of cost forecast hikes - as the alliance membership increases by one, the cost goes up by a third on average. We also find a statistically significant association of cost hikes with stakeholder interactions - bringing in one stakeholder increases cost by $0.73 \%$ on average, whereas trading with a stakeholder increases cost by $0.39 \%$ on average; the growth of the supply chain has no statistically significant association with the overall cost escalation.

Model 2 shows that the direct participation of stakeholders in governance stays positively associated with cost hikes: letting a stakeholder in causes $1.16 \%$ cost hike on average. But there is no longer a statistically significant link with individual trading with stakeholders; and only a marginal impact with the supply chain growth $(0.2 \%, p<0.05)$.

Model 3 shows no statistically significant association between late cost hikes and stakeholder interactions, irrespective of the form of governance. But the supply chain growth is positively associated with late costs hikes, although the effect is moderate: when the number of suppliers increases by one, cost escalation increases by $0.19 \%$.

\section{References}

Allison, P. D. 2009. Fixed effects regression models. London: Sage.

Bartels, B. 2008. Beyond" fixed versus random effects": a framework for improving substantive and statistical analysis of panel, time-series cross-sectional, and multilevel data. The Society for Political Methodology, 9: 1-43.

Greene, W. 2000. Econometric analysis. New York, NY: Macmillan.

Gujarati, DN, \& Porter, DC 2009. Basic econometrics (5th ed.). New York: McGraw Hill.

Hausman, JA 1978. Specification tests in econometrics. Econometrica, 46(6): 1251-1271.

Stock, J. H., \& Watson, M. W. 2007. Introduction to econometrics (2nd ed.). Boston: Pearson Addison Wesley. 
Table 2: Crossrail Governance, Value Creation and Distribution, and Cost Escalation with Illustrative Quotations (from Primary Material)

\section{Shared Governance Core Formation}

Pooling Essential Resources "The central part of London couldn't be done without TfL's cooperation because the scheme involved links to a lot of Underground lines.... So that was why we felt it was

to Value Creation

necessary to have a joint venture... the sponsor board is made up of TfL and the DfT and the chairmanship rotates between the two of them"

Negotiating an Unifying "Any project that is a JV between capital and national governments is a complete bloodbath in the sense both politicians believe they've a mandate, national or city-wide,

Value Distribution over the project... the Mayor/TfL and DfT had different agendas ... who owned what and where it went was a hassle...there was a lot of disputes .... it all went back to this premise that once you get the politics right, financing comes after the politics"

"Rolling stock [train cars] is a nightmare...TfL's view is that all rolling stock is bought on behalf of TfL and so is on the balance sheet. But DfT view is that rolling stock is off balance sheet...so, go and buy a PFI ... If you've got part of your client body that does want to do it [PFI] and part that doesn't, it's going to be a real bumpy ride"

Cost Escalation and

Value Creation
“When the original scheme was promoted, Canary Wharf didn't exist. The changes that were made to the economic geography of London were so important that we felt Crossrail needed to be extended to link Canary Wharf and enable a link to southeast London, which is quite poorly served. So we expanded the remit of Crossrail quite a bit"

Lead-role Governance Expansion 


\begin{tabular}{|c|c|}
\hline Essential Stakeholder & "If you are building in the middle of London, you need Council consent for everything that you do, your hours of work, lorry movements, how much noise and dust you \\
\hline & $\begin{array}{l}\text { "For the work on the national railway, we have a partnership arrangement with Network Rail to undertake the works on our behalf...£2.3bn of work that can be sourced } \\
\text { through their regulatory asset base... we've got to get our systems technology to work with their technology... the thing that will make or break Crossrail is the systems" }\end{array}$ \\
\hline Collective Action to Motivate & "We reached a point where the Treasury was saying 'no you can't have any more money to have the Woolwich station and the Parliamentary Select Committee was \\
\hline Voluntary Resource & saying 'we'll refuse to report the Bill unless there's a station'. We then did a deal with Berkeley Homes, the landowners - they would build the station box on their land, so \\
\hline Contributions & $\begin{array}{l}\text { no real procurement issues... They [Greenwich Council, Berkeley Homes] desperately wanted a station and made several public statements they would be contributing } \\
\text { financially" }\end{array}$ \\
\hline & $\begin{array}{l}\text { "There is a debate going on about the Crossrail seating arrangement... some people are saying we should get rid of the cross seats and put just longitudinal seats to } \\
\text { increase capacity ... but BAA, which is putting } £ 240-£ 280 \text { million into Crossrail is not going to be happy with a train that looks like a big tube" }\end{array}$ \\
\hline Polycentric governance & \\
\hline & $\begin{array}{l}\text { "Every station site is almost a stand-alone project with an unique set of stakeholders... the infrastructure maintainer for each station and the composition of the groups that } \\
\text { represent the residents are all different ...We just went to see them [local authorities/LAs] and said 'this is what [the station] we're proposing'. We tried to accommodate } \\
\text { their wishes as far as possible; things like an additional entrance here and there, or sorting out the tunneling strategy so that it caused the least disruption" }\end{array}$ \\
\hline Cost Esc & \\
\hline Value Creation & $\begin{array}{l}\text { "We've a multitude of interested parties, high potential for cost discussion... as soon as you talk to a stakeholder about getting permission for anything, you're on a hiding } \\
\text { to nowhere" }\end{array}$ \\
\hline
\end{tabular}




\begin{abstract}
Essential Stakeholder
"'In Farringdon station, our stakeholders include local residents and businesses, a school (because of children's safety as vehicles pass), a meat market (we cannot raise argument why a certain thing cannot be done. There may be a subtext that it's too expensive, but that's not the prime reason; the arguments are based on the merits of the proposals that are brought forward"
\end{abstract}

"We had very vehement opposition from the Whitechapel area... they were worried that the tunnels going underneath would cause settlements and cracking"

Bilateral Agreements to Acquire Stakeholder

Resources

Cost Escalation and Socia

Value Creation

capital-intensive

buyer-supply chain

High uncertainty

High asset specificity

Supplier opportunism claims

"We wanted suppliers to work harder, not give 100 excuses as to why they couldn't do it. [But] that is the sort of contractual environment we are... public sector demands that level of fairness and balanced approach; if you manage risk correctly, you place it with suppliers, the people best able to deal with it. Sweat equity always works"

Cost Escalation and Social

Value Creation

"Anybody can raise a parliamentary petition... and the Select Committee can order changes to the scheme, or say to the petitioner 'we're sorry, but you just have to put up with it...Probably $60 \%$ or $70 \%$ of the petitions are settled outside the Committee room. We just tell the Committee this petition is not going to appear because they have been given an undertaking or assurance to do something. We made 750 individual commitments that we've to abide by so that at the end we can say 'we did all that"”

"Any concession that has limited financial implications is easy to agree; some of the things were quite big though, and that's more difficult. For example, the Corporation of London wanted an additional entrance at the Liverpool Street station. We argued for nearly two weeks. In the end, we agreed to provide an extra entrance"

\section{Supply chain Expansion}

We are a very thin client. We're basically leaving the [civil] contractors to deliver for us; we've got thin project management functions to do that Our model is big contracts whereby we aren't particularly integrated; we elected not to be. We have a lot of capability out there and we've paid a fee for that. We want to work with suppliers in a collaborative way, but basically with few interfaces, quite deliberately. We've bought management resource in these contracts...we have between 300 and 350 interfaces"

'Things will change as the project advances; they always do. No one is clever enough to think about all the things that are going to happen in ten years' time...The biggest thing about working underground is that you never quite know what you're going to find... so it is discovery that is the biggest challenge"

“In civils, we've contracts up to $£ 1$ billion...not many companies in the world even in a JV that can bear that ..we've quite a lot of risk...so they've hard-nosed $50-50$ pay-gain share on them so we're not going to let them off lightly; and the system areas also have some really hefty penalties in them should suppliers not perform. We need that Signaling are tiny contracts, but if the signaling contract doesn't work, then Crossrail doesn't work. So the risk there proportionally is enormous'

"Rolling stock is caught in the perfect storm. And you could look at that storm in terms of sustainability, triple bottom line...we've also got the social sustainability piece being played well by the unions whereby you've got a manufacturer in Derby who has been very high-profile

"Politically we are as much as a big transport system as about a big project to keep the construction industry on its feet...It's about SMEs, learning skills and training, keeping people off street... The construction industry is literally on its knees at times, the economy is on a low ebb, it needs infrastructure projects" 


\section{REFERENCES}

Baldwin, C. Y., \& Clark, .K B. 2000. Design Rules, Volume 1: The Power of Modularity. Cambridge, MA: MIT Press.

Baldwin, C. Y. 2008. Where do transactions come from? Modularity, transactions, and the boundaries of firms. Industrial and Corporate Change, 17(1): 155-195.

Baldwin C, Y. 2019. Transaction Free Zones. Working paper, Harvard Business School, Cambridge, MA.

Barney, J. B. 2018. Why resource-based theory's model of profit appropriation must incorporate a stakeholder perspective. Strategic Management Journal. 39(13): $3305-3325$.

Bartels, B. 2008. Beyond" fixed versus random effects": a framework for improving substantive and statistical analysis of panel, time-series cross-sectional, and multilevel data. The Society for Political Methodology, 9: 1-43.

Bourgeois, L. J. 1981. On the measurement of organizational slack. Academy of Management Review, 6(1): 29-39.

Bridoux, F., \& Stoelhorst, J. W. In-press. Stakeholder governance: Solving the collective action problems in joint value creation. Academy of Management Review.

Camerer, C., \& Knez, M. 1997. Coordination in organizations: A game-theoretic perspective. In Shapira (Ed.), Organizational Decision Making: 158-188. Cambridge, UK: Cambridge University Press.

Chandler, A. D. 1962. Strategy and structure: Chapters in the history of the American enterprise. Cambridge, MA: MIT Press.

Charles, H. 1931. Collected Papers of Charles Sanders Peirce. In A. W. Burks (Ed.), Science and Philosophy, vol. 7. Cambridge, MA: Harvard University Press.

Cyert, R. M., \& March, J. G. 1963. A behavioral theory of the firm, vol. 2. Englewood Cliffs, NJ: Prentice-Hall.

Davies, A., MacAulay, S., DeBarro, T., \& Thurston, M. 2014. Making innovation happen in a megaproject: London's crossrail suburban railway system. Project Management Journal, 45(6): 25-37.

Davies, A., \& Mackenzie, I. 2014. Project complexity and systems integration: Constructing the London 2012 Olympics and Paralympics Games. International Journal of Project Management, 32(5): 773-790.

Denicol, J., Davies, A., \& Krystallis, I. 2020. What Are the Causes and Cures of Poor Megaproject Performance? A Systematic Literature Review and Research Agenda. Project Management Journal, 51(3): 328-345.

Denis, J.-L., Dompierre, G., Langley, A., \& Rouleau, L. 2011. Escalating indecision: Between reification and strategic ambiguity. Organization Science, 22(1): 225244.

Denis, J.-L., Langley, A., \& Rouleau, L. 2006. The power of numbers in strategizing. Strategic Organization, 4(4): 349-377. 
Dietz, T., Ostrom, E., \& Stern, P. C. 2003. The struggle to govern the commons. Science, 302(5652): 1907-1912.

Dorobantu S, Kaul A, Zelner B 2017. Nonmarket strategy research through the lens of new institutional economics: An integrative review and future directions. Strategic Management J. 38(1) 114-140

Eisenhardt, K. M. 1989. Building theories from case study research. Academy of Management Review, 14(4): 532-550.

Eisenhardt, K. M., \& Graebner, M. E. 2007. Theory building from cases: Opportunities and challenges. Academy of Management Journal, 50(1): 25-32.

Fehr, E., \& Gintis, H. 2007. Human motivation and social cooperation: Experimental and analytical foundations. Annual Review Sociology, 33: 43-64.

Flyvbjerg, B., Holm, M. S., \& Buhl, S. 2002. Underestimating costs in public works projects: Error or lie? Journal of the American Planning Association, 68(3): 279-295.

Frischmann, B. M. 2005. Infrastructure and commons management. Minnesota Law Review, 89: 917-1030.

Frischmann, B. M. 2012. Infrastructure: The social value of shared resources. Oxford: Oxford University Press.

Frooman, J. 1999. Stakeholder influence strategies. Academy of Management Review, 24(2): 191-205.

Garcia-Castro, R., \& Aguilera, R. V. 2015. Incremental value creation and appropriation in a world with multiple stakeholders. Strategic Management Journal, 36(1): 137-147.

Gatignon, A, \& Capron, L. In-press. The firm as an architect of polycentric governance: Building open institutional infrastructure in emergent markets. Strategic Management Journal.

Gibbons, R., \& Henderson, R. 2012. Relational contracts and organizational capabilities. Organization Science, 23(5): 1350-1364.

Gil, N., \& Baldwin, C. 2013. Creating a design commons: Lessons from teachers' participation in school design. Working paper. No. 14-025, Harvard Business School, Cambridge, MA.

Gil, N. 2009. Developing cooperative project client-supplier relationships: How much to expect from relational contracts? California Management Review, 51(2): 144169.

Gil, N., \& Lundrigan, C. 2012. London 2012: The regeneration games. Case study series, Alliance Manchester Business School. The University of Manchester, UK

Gil, N., \& Lundrigan, C. 2012a. BAA Heathrow: The intelligent client. Alliance Manchester Business School, The University of Manchester, Manchester, UK

Gil, N., \& Lundrigan, C. 2013. Crossrail: The perfect storm. Alliance Manchester Business School, The University of Manchester, Manchester, UK 
Gil, N., \& Pinto, J. K. 2018. Polycentric organizing and performance: A contingency model and evidence from megaproject planning in the UK. Research Policy, 47(4): 717-734.

Gil, N., \& Tether, B. S. 2011. Project risk management and design flexibility: Analysing a case and conditions of complementarity. Research Policy, 40(3): 415-428.

Hardin, G. 1968. The tragedy of the commons. Science, 162(3859): 1243-1248.

Hirschman, A. O. 1967. Development projects observed. Washington, DC: Brookings Institution.

Johnson, R. N., \& Libecap, G. D. 2001. Information distortion and competitive remedies in government transfer programs: The case of ethanol. Economics of Governance, 2(2): 101-134.

Kahneman, D., \& Lovallo, D. 1993. Timid choices and bold forecasts: A cognitive perspective on risk taking. Management Science, 39(1): 17-31.

Klein, P. G., Mahoney, J. T., McGahan, A. M., \& Pitelis, C. N. 2012. Who is in charge? A property rights perspective on stakeholder governance. Strategic Organization, 10(3): 304-315.

Klein, P. G., Mahoney, J., McGahan, A. M., \& Pitelis, C. N. 2019. Organizational governance adaptation: Who is in, who is out, and who gets what. Academy of Management Review, 44(1): 6-27.

Lenfle, S., \& Loch, C. 2010. Lost roots: How project management came to emphasize control over flexibility and novelty. California Management Review, 53(1): 3255.

Libecap, G. D. 1978. The evolution of private mineral rights: Nevada's Comstock Lode. New York: Arno Press.

Libecap, G. D. 1989. Contracting for property rights. Cambridge, UK: Cambridge University Press.

Love, P. E. D., Ahiaga-Dagbui, D. D., Smith, S. D., Sing, M. C.-P., \& Tokede, O. 2018. Cost profiling of water infrastructure projects. Journal of Infrastructure Systems, 24(4): 4018023.

Lundrigan, C. P., Gil, N. A., \& Puranam, P. 2015. The (under) performance of mega-projects: A meta-organizational perspective. Academy of Management Proceedings. Briarcliff Manor, NY: Academy of Management.

March, J. G., \& Sutton, R. I. 1997. Crossroads-organizational performance as a dependent variable. Organization Science, 8(6): 698-706.

Merrow, E. W., McDonnell, L. M., \& Arguden, R. Y. 1988. Understanding the outcomes of megaprojects. Santa Monica, CA: The RAND Corporation.

Miles, M. B., \& Huberman, A. M. 1984. Qualitative data analysis: A sourcebook of new methods. Qualitative data analysis: a sourcebook of new methods. Thousand Oaks, CA: Sage. 
Miller, R., \& Lessard, D. R. 2000. The strategic management of large engineering projects: Shaping institutions, risks, and governance. Cambridge, MA: MIT Press.

Mitchell, R. K., Agle, B. R., \& Wood, D. J. 1997. Toward a theory of stakeholder identification and salience: Defining the principle of who and what really counts. Academy of Management Review, 22(4): 853-886.

Mohr, J. J., Fisher, R. J., \& Nevin, J. R. 1996. Collaborative communication in interfirm relationships: moderating effects of integration and control. Journal of Marketing, 60(3): 103-115.

Mohr, J., \& Spekman, R. 1994. Characteristics of partnership success: partnership attributes, communication behavior, and conflict resolution techniques. Strategic Management Journal, 15(2): 135-152.

Moore, M. H. 1995. Creating public value: Strategic management in government. Cambridge, MA: Harvard University Press.

Morris, P. W. G. 1994. The management of projects. London: Thomas Telford.

Morris, P. W. G., \& Hough, G. H. 1987. The anatomy of major projects: A study of the reality of project management. NY: John Wiley and Sons.

Nutt, P. C. 1999. Public-private differences and the assessment of alternatives for decision making. Journal of Public Administration Research \& Theory, 9(2) 305-50.

Odziemkowska, K, Dorobantu, S. 2021. Contracting Beyond Market. Organization Science. Published online in Articles in Advance 7 Jan.

Olson, M. 1965. The logic of collective action: Public goods and the theory of groups. Cambridge, MA: Harvard University Press.

Ostrom, E. 1990. Governing the commons: The evolution of institutions for collective action. Cambridge, UK: Cambridge University Press.

Ostrom, E., Walker, J., \& Gardner, R. 1992. Covenants with and without a sword: Self-governance is possible. American Political Science Review, 86(2): 404-417.

Ostrom, E. 2005. Understanding institutional diversity. New Jersey: Princeton University Press.

Pfeffer, J., \& Salancik, G. R. 1978. The external control of organizations: A resource dependence perspective. New York: Harper Row.

Pitsis, TS, Clegg, SR, Marosszeky, M, \& Rura-Polley, T. 2003. Constructing the Olympic dream: a future perfect strategy of project management. Organization Science, 14(5): 574-590.

Podsakoff, P. M., MacKenzie, S. B., Lee, J.-Y., \& Podsakoff, N. P. 2003. Common method biases in behavioral research: A critical review of the literature and recommended remedies. Journal of Applied Psychology, 88(5): 879.

Porter, T. M. 1995. Trust in numbers: The pursuit of objectivity in science and public life. Princeton, NJ: Princeton University Press. 
Powell, W. 2003. Neither market nor hierarchy: Network forms of organization. In B. M. Staw \& L. L. Cummings (Eds.), Research in organizational behavior, vol. 315: 104-117. Greenwich CT: JAI Press.

Rittel, H. W. J., \& Webber, M. M. 1973. Dilemmas in a general theory of planning. Policy Sciences, 4(2): 155-169.

Scott, WR 1995. Institutions and organizations (2nd ed). Thousand Oaks: Sage.

Shenhar, A. J., \& Dvir, D. 2007. Reinventing project management: the diamond approach to successful growth and innovation. Cambridge, MA: Harvard Business School Press.

Siggelkow, N. 2007. Persuasion with case studies. The Academy of Management Journal, 50(1): 20-24.

Simon, H. A. 1962. The architecture of complexity. Proceedings of the American Psychological Association, 106(6): 467-482.

Staw, B. M. 1981. The escalation of commitment to a course of action. Academy of Management Review, 6(4): 577-587.

Staw, B. M., \& Ross, J. 1989. Understanding behavior in escalation situations. Science, 246(4927): 216-220.

Stinchcombe, A. L., \& Heimer, C. A. 1985. Organization theory and project management: Administering uncertainty in Norwegian offshore oil. Bergen: Norwegian University Press.

Tee, R, Davies, A, Whyte, J. 2018. Modular designs and integrating practices: Managing collaboration through coordination and cooperation. Research Policy, 48 (1) 51-61

Tversky, A., \& Kahneman, D. 1974. Judgment under uncertainty: Heuristics and biases. Science, 185(4157): 1124-1131

Thompson, F., \& Jones, L. R. 1986. Controllership in the public sector. Journal of Policy Analysis and Management, 5(3): 547-571.

Van de Ven, A. H. 2007. Engaged scholarship: A guide for organizational and social research. Oxford: Oxford University Press.

Van Lange, P. A. M., Joireman, J., Parks, C. D., \& Van Dijk, E. 2013. The psychology of social dilemmas: A review. Organizational Behavior and Human Decision Processes, 120(2): 125-141.

Verweij, S., van Meerkerk, I., \& Korthagen, I. A. 2015. Reasons for contract changes in implementing Dutch transportation infrastructure projects: An empirical exploration. Transport Policy, 37: 195-202.

Wachs, M. 1989. When planners lie with numbers. Journal of the American Planning Association, 55(4): 476.

Williamson, O. E. 1985. The economic institutions of capitalism: firms, markets, relational contracting. New York: Free Press.

Williamson, O. E. 1990. Transaction cost economics and organization theory. In O. E. Williamson (Ed.), Organization theory: from Chester Barnard to the present and beyond: 207-256. Oxford: Oxford University Press. 
Williamson, O. E. 1993. Transaction cost economics and organization theory. Industrial and Corporate Change, 2(2): 207-256.

Williamson, O. E. 2003. Examining economic organization through the lens of contract. Industrial and Corporate Change, 12 (4) 917-942

Winch, G. 2010. Managing construction projects: Information processing approach (2nd ed.). Oxford: Wiley-Blackwell.

Wood, D. J., \& Gray, B. 1991. Toward a comprehensive theory of collaboration. Journal of Applied Behavioral Science, 27(2): 139-162

\section{AUTHOR BIOS}

Nuno Gil is a Professor of New Infrastructure Development at the Alliance Manchester Business School, The University of Manchester, UK. He received a $\mathrm{PhD}$ in Civil and Environmental Engineering at University of California at Berkeley. He focuses his research on the design of structures and processes can bring the best of people.

Yongcheng $\mathbf{F u}$ is a research associate in the College of Management and Economics, Tianjin University, China. He received his $\mathrm{PhD}$ degree in Business and Management from the Alliance Manchester Business School, The University of Manchester. His research focuses on the organizational governance of megaprojects. 